\title{
An Evaluation of the Communication Problems between Nurse Candidates and Patients in Terms of Adult Coaching
}

\author{
Hayat Boz*a ${ }^{* a}$ Sevinç Dereli ${ }^{\mathrm{b}}$
}

\begin{tabular}{l} 
Article Info \\
\hline DOI: $10.14686 /$ buefad.407786 \\
\hline Article History: \\
Received $\quad 19.03 .2018$ \\
Accepted $\quad 31.03 .2018$ \\
Published $\quad 31.10 .2018$ \\
\hline Keywords: \\
Prospective nurse, \\
Patient, \\
Communication, \\
Adult coaching. \\
\hline Article Type: Research Article
\end{tabular}

\begin{abstract}
This research aims to identify the hardships that the nurse candidates confront at their internship clinics while patient-caring and coaching, to specify the conflicts between them and the patients in accordance with their own feedbacks, and to evaluate these problems in terms of adult coaching. The study group chosen from 12th grade students of Anatolia Medical Vocational High School- Nursing Department were 12 nurse candidates, who were studying Skills training in 2 different teaching hospitals, have had face-to-face individual meetings with. The findings were as follows: Trainee nurses have faced problems such as resistance to the treatment, refusal, crying out, communication issues, unnecessary demands, repelling out of the room, and pre-judcement, and they have attempted to overcome these problems by establishing empathy and roll-modeling other nurses. While facing out extra-and-unrelated workload with other medical personnel, they have also had problems like being seen as a servant and as a selfish person by the patients' relatives. Nurse candidates did not only suggest that they have become more conscious about the communication problems due to the interviews, but they have also learned how to utilize their experiences as a means to detect possible solutions and so not being as helpless as they were before.
\end{abstract}

\section{Yetişkin Eğitimi Açısından Hemşire Adayları İle Hastalar Arasındaki İletişim Sorunlarının Değerlendirilmesi}

\begin{tabular}{l} 
Makale Bilgisi \\
\hline DOI:10.14686/buefad.407786 \\
\hline Makale Geçmişi: \\
Geliş $\quad 19.03 .2018$ \\
Düzeltme $\quad 31.03 .2018$ \\
Kabul $\quad 31.10 .2018$ \\
\hline Anahtar Kelimeler: \\
Hemşire adayı, \\
Hasta, \\
Iletişim, \\
Yetişkin eğitimi. \\
\hline Makale Türü: Araştırma \\
makalesi \\
\end{tabular}

$\ddot{\mathbf{O}} \mathbf{z}$

$\mathrm{Bu}$ araştırmanın amacı hemşire adaylarının staj yaptıkları kliniklerde hasta bakımı ve eğitim hizmeti sunarken karşılaştıkları güçlükleri, yetişkin hastalarla aralarında yaşanan iletişim çatışmalarını ve yaşadıkları sorunları, kendilerinin görüşleri doğrultusunda belirlemek ve bu sorunları yetişkin eğitimi açısından değerlendirmektir. Çalışma grubu, Anadolu Sağlık Meslek Lisesi Hemşirelik Bölümü 12. sınıf tan seçilen, 2 farklı Eğitim Hastanesinde Beceri Eğitimi yapan 12 hemşire adayı ile yüz yüze bireysel görüşmeler sonucu gerçekleştirilmiştir. Elde edilen sonuçlar şöyledir: Hemşire adayları kliniklerde hastalarla, tedaviye uymama, reddetme, ağlama, dil problemleri, gereksiz istekler, odadan kovma, önyargılar gibi sorunlar yaşamışlar ve bu sorunlarla da öncelikle empati kurarak ve diğer hemşireleri rol model alarak baş etmeye çalışmışlardır. Diğer sağlık personelleriyle de gereksiz ve alakasız iş yükü, acımasız ve anlayışsız davranışlar şeklinde sorun yaşarken, hasta yakınlarıyla da, hizmetçi gibi görülme, bencillik gibi sorunlar yaşamışlardır. Hemşire adayları görüşmeler sayesinde yaşadıkları iletişim sorunlarıyla daha bilinçli şekilde yüzleşmişler, farkında olmuşlar ve yaşadıkları deneyimleri bilgiye ve çözüm üretmeye dönüştürerek bundan sonra çaresizlik yaşamayacaklarını belirtmişlerdir.

\footnotetext{
*Corresponding Author: hboz@education ankara.edu.tr

a Assoc. Prof Dr. Hayat Boz, Ankara University, Ankara Turkey, https://orcid.org/0000-0001-5409-8371

bevinç Dereli, Ankara University, Ankara Turkey, https://orcid.org/0000-0002-1535-4042
} 


\section{Introduction}

In recent years, communication has been of a large importance because it acts as a key in interpersonal relations. However, sometimes there might occur some communication-hardening situations. It is accepted that communication and communication skills have a vital role on nursing education and application, and that ineffective communication leads to frustrating problems in terms of quality and quantity (Özcan, 2006:98).

Kron (1966), defines medical vocational schools and health facilities as establishments where the power and authority were concentrated at the top. For Kron, nurses are people who are self-sacrificing, humble and readyto-serve for others, so they are not necessarily willing to state their thoughts and feelings. They get ready for the role to serve. They were expected to be a part of the medical team, not the decision-making mechanism; indeed, they are so occupied that they do not look after their rights (Kron, 1966; Özcan, 2006).

It was supposed that nursing schools encourage and train students to be more self-confident, able to decide autonomously, aware of what practice they do, and capable of controlling their anxiety, helplessness and fury caused by exhaustion not to constitute further conflicts between them and the patient companions. If nurse candidates get such a support from their colleagues in the facilities where they practiced skills training and Internship, they shall improve themselves as an individual and a member of the occupation, and be capable of working out the problems they encounter with the patients by determining the correct parameters (Özcan, 2006).

In health facilities, Anatolia Medical Vocational High School students who took skills trainings three times and 8 hours a week in 11th and 12th grades run into several communication problems with the adolescent patients that they nurse in clinics. These problems resulted in challenges in the delivery and acquisition of health-care system. In this research, it was aimed to determine the hardships of a group of 12th grade nurse candidates in Anatolia Medical Vocational High School while offering patience-care service, patient education for specific needs and health-care service. To determine the communication conflicts and deficiencies experienced with patients in accordance with their own will, and also to evaluate these problems considering adolescent coaching are aimed. With regard to this objective, the answers of the following questions are sought.

1- What are the demographic characteristics of the participants?

2- What are the problems the nurse candidates face in the clinics they practice?

3- Do these problems cause conflicts in communication?

4- What do they do about the problems faced?

5- Do they face any problems with patient-companions and other medical personnel?

6- Do they have suggestions related to these problems?

This research, conducted between April 21 and June 9 2017, was restricted with the data and remarks obtained with 12 nurse candidates in total -nine studying Skills training in Ankara Numune Education And Research Hospital, and three studying Skills training in Ankara Highly Specialized Education and Research Hospital- by using semi-structured interview forms.

\section{Method}

This study has been completed by using semi-structured interview technique, which is a qualitative research technique. The most substantial convenience that semi-structured interviewing technique offers the researcher is that it presents a more systematic and comparable data since it is based on a preset interviewing protocol. From this aspect, it is a more appropriate researching style for education-science studies (Yıldırım \& Şimşek, 2005).

\section{The Study Group}

The study group of this research group was made up of twelve 12th grade nurse candidates studying skills training three days and eight hours a week in MEB Anatolia Medical Vocational High School Program, Nursery Department, Ankara Numune Education and Research Hospital (ANEAH) and Ankara Highly Specialized Education and Research Hospital (AYIEAH). 
The following are the reasons why nominees are selected from 12th grades:

-The candidates had had Skills training 3 days and 8 hours a week in the 11th grade and completed their summer training too,

-They found out about the communication problems with patients they nursed and gained awareness,

-They were supposed to produce solutions by setting up a more conscious and professional interaction in the future.

These are the reasons why the research has been conducted in the above-mentioned hospitals:

1- Ankara Numune Education and Research Hospital, as the oldest health facility in Ankara, has been

providing service since 1800s. For its number of personnel and patients, its success in treatment and care, its patients' and patient-companions' sociological, psychological and cultural characteristics' reflecting Turkey's inlay precisely, its variety in cases. Since it is also an educational hospital, it is a facility that enriches its students' skills, technical knowledge, good manners and experiences. Out of this hospital, interviews have been done with 9 students in total -1 male, 8 female.

2- Ankara Highly Specialized Education and Research Hospital, as one of the largest Specific Branch Hospitals in Turkey, is a good example of group work with its staff that has achieved enormous successes in the field of Cardiovascular Surgery for more than 50 years. In this hospital, nurse candidates are able to improve themselves vocationally. 3 students -1 male, 2 female have been interviewed out of this hospital.

\section{Instrument}

The interviews have been conducted between April 21 - June 9 2017, with the permission of the responsible nurses in clinics, where prospective nurses practice. The practicing hours were in their internship days and in the afternoons and evening hours when they would be less occupied. An interview protocol and an interview form consisting of 7 questions were created, and with each of the nurse candidates, 15 to 25 minutes of interviews were held so as to give them room to express themselves comfortably.

During the interviews, the interviewees were numbered as G1, G2, respectively. All of meetings were held in accordance with the interviewing protocol, in an atmosphere where there is effective listening, sincerity and reliability. In order to keep the data better, a voice recorder was also used throughout the interviews.

In the analysis of the research data, descriptive analyzing technique was used. Descriptive analyzing technique is a technique in which the data is interpreted and summarized according to the preset themes, direct citations are used in order to remark the interviewed individuals' views effectively, and the obtained results are evaluated based on the reason-result connections (Yıldırım \& Şimşek, 2005).

The interviews were written down, and the data gathered was interpreted in frame of the research questions. In addition to this, in order to reflect the views of the interviewees, direct quotations were often utilized in the descriptive analysis of the findings.

The proper names of the nurse candidates were codified so as to protect the principles of privacy. Therefore, each interview was coded as "G", and each interviewee was numbered as "G1, G2, G3, G4, G5...G12".

\section{Findings and Interpretations}

In this section of the research, the questions in the interview form were grouped in accordance with the problems and the findings are presented. The nurse candidates, having similar demographic qualities, age between 17 and 19. The group consists of 2 male and 10 female 12th grade students who have been taking Skills training in hospitals 3 days a week and 8 hours a day for 2 years. 


\section{Clinics where nurse candidates have skills training during the interviews and demographic information of patients treated in these clinics}

Every adolescent patient cared by nurse candidates had unique characteristics. Since each patient had different perceptions of themselves, age, illness, hospitalization, and treatments applied, their reactions will also differ. To get to know the individual, the nurse candidate should first collect information. She collected this information directly from the patient's file, the doctor, observations of other nurses and indirect interactions with the patient, monitoring and evaluating the clues directly or indirectly through the patient's interpersonal relationships (Özcan, 2006).

Nurse candidates said that they did their internships in various clinics and policlinics of hospitals G1, G2, G7 and G11 in the Internal Medicine Clinics (Cardiology, Gastroenterology, Hematology, General Internal Medicine). While G3, G8 and G9 in the Surgical Clinics (Urology, General Surgery, Thoracic Surgery), G5 in the Emergency Medicine Clinic, and G4, G6, G10 and G12 in various policlinics (Child, Chronic Wound, Liver Bile)

For the demographic information of the patients they served, all candidates apart from G4 stated that they were between the ages of 35 and 45 and mostly met with male patients. G4 remarked "Children ranging from newborns to 17 years-olds come in. Ratios of male \& female are the same".

While G2 said "It surprises me a lot that there are lots of people who have never been educated alongside the fact that there are many primary school graduates", and G7 said "Mostly primary school graduates, but the proportion of the high school and university graduates are undeniable.", other candidates stated about their patients' educational backgrounds that they were mostly primary school graduates.

According to the statements of the nurse candidates, findings show that despite the fact that they practice at different clinics, the majority of the patients they meet are composed of adult, male, primary school graduates.

When "Do you have difficulty communicating with adults in this age group?" was asked during the interview, G3 and G9 answered "Generally, I think of my mother, father and relatives, I want to treat patients like we do to them, but I don't want the patient to get spoiled. I am especially afraid of being misunderstood by male patients, I think that he won't care about me but I am scared of not being able to keep the distance. I sometimes have difficulty in starting the conversation". It was thought that these nurse candidates (G3, G9) did not have adequate knowledge about the behavioral characteristics of developmental periods of the adults, that their self-recognition process is not yet fully developed and that their self-development is not yet completed enough to establish an occupational relationship. The other 10 candidates stated that they did not have difficulty in communicating.

\section{Communication problems encountered by nurse candidates while providing patient care services}

Troublesome situations that were experienced in health institutions, which prevent communication, were caused by doctors, nurses or patients, diseases, failure of treatment, problems in health system and inadequate social support. Patients with communication-hampering behaviors were generally referred to as "difficult patients" or "problem patients" (Macdonald M. 2003, act: Göral, 2011). Studies indicated that male patients between the ages of 20-40 who are unemployed, in a low education level, with personality disorders were mostly difficult ones (Koekkoek B., Meijel B., Hutschemaekers G. 2006, act, Göral, 2011). In addition, difficult patients have been stated to be more aggressive, dangerous, interested, crying, not cooperating, not verbally communicating, unaware of the rules, anxious, lying, scared, stubborn, confused, seductive, disruptive, with unexplained symptoms (symptom of illness), unhygienic and disregarding care and treatment patients. In addition, difficult patients are mostly seen in surgery, cardiology, pediatrics, geriatrics, psychiatry, oncology clinics and emergency services (Wolf Z.R., Smith G.R., 2007: act, Göral, 2011).

It seems inevitable that nurse candidates had problems in terms of the age of the patients, the majority of the male patients, the difficulties they face in terms of the clinics they are practicing with, and the communication problems. Their responses to the questions were as follows. 
G1: That patients are cardiac and that they stay a long time in the clinic I work at are increasing problems. They are so worried and fearful. When I go to treatment, they react harshly. They are shouting with expressions such as "do not touch me"' or 'go and call nurse". Even if all the patients do not do the same thing, I mostly get the same reactions from male patients. The patients are always wandering around, which causes treatment times hinder, then I have to find them. The patients object to treatment and patient care time, and they oppose against their treatment. They use some expression like you have just injected or you will be measuring my blood pressure, again. I sometimes have to give the medicine while the patient walking on the corridor instead of giving by orally.

G2: I cannot say that I have a lot of communication problems. However, some patients might cause a problem due to their illnesses and hospital atmosphere. They refuse the treatment that must be administered. Since I am a male, they do not want me to treat them; they think that I can hurt them. Some of them want to heal immediately. When their troubles last long, they show off some behavioral disorders such as yelling, swearing, crying. There are also ones who give up the treatments and leave the hospital. Patients are very prejudiced against nurses, especially intern nurses. After their doctors come, they feel more comfortable.

G3: It is not possible not to have a problem in our department. Patients are very prejudiced against us. Since male patients are more, they are furious. They sometimes cannot endure pains, and then they are yelling, which makes me so worried. At that time, I want to go right to them, but elder nurses are stopping me. They say that we have just injected his/her painkiller, s/he is trying to draw your attention and s/he will shut up soon. However, it is strange but when the patients come across with their doctors, they say that yes, my pains have stopped, I feel relaxed now. They can make unnecessary requests. For example, do you have a cigarette, my visitor will bring me a lunch, do not interfere etc. At the treatment time, they do not fidget. They want to arrange the time according to themselves. Especially, they mess with our work. I sometimes figure out that the male patients see me as a sexual object. However, I can get over thanks to my teachers' advice and elder nurses' behaviors. Recently, there have also been foreign patients from other nations. I have a language problem with them, as well.

G4: In spite of not being often, I have problems from time to time. I face more problems with patient relatives because I work at child policlinic. The children are having difficulties with doctors and me in the treatment. Since there are not nurses at the policlinic, it is my work that I soothe them and draw their attentions. If it is a foreign patient, our work is getting complicated. Children are getting coward and agitated. Also, children who do not care about hygiene may come to hospital. It is really difficult to educate relatives of children.

G5: I do not have a communication problem with the patients. In our department, the patients are not kept too much, circulation is also too much. After immediate treatment and controls, they are sent to other clinics and hospitals. The department is so crowded, relatives of the patients are quite nervous; therefore, I sometimes have a problem with them.

G6 \& 10: I have problems with at least 3 out of 10 patients every day. It is a hectic policlinic. The problem I most often face is that the patients do not follow the recommended treatment, they do not use the medicine given by the doctor nor do the wound care regularly at home. Without doing what is said, they come to the control and because the healing does not take place, the treatments are prolonged, finally they have the feeling that they have not fulfilled their expectations and they are raging. We have many patients from outside of city. Since the number of beds for inpatient treatment is very low, the patients who do not have money and any place to stay can stay in hygienic environments. This means that the wound can proceed, grow gangrene, and even lead to cut your leg, so they always want their priority and they do not care of treatment sequence. I'm having trouble convincing them. I am having difficulty in telling how to use medicines properly to illiterate people. Although I repeat many times, after I ask them how to do it if they cannot respond my question, I start to be angry because I think they have never listened to me, but I try not to reflect my feelings. Many do not know their rights and can be treated unfairly by other staff about treatment priority and bed finding. When I observe it, I cannot intervene because I am a student and I feel unhappy. I have also language problems with strangers. I am trying to communicate together with an interpreter. This is also very difficult. 
G7: Most of the patients are very sensitive because they have cancer. They even make sense out of our gestures. They are always asking questions about time, series, news, marriage, friend etc. They see me as inexperienced because I am an intern student. They do not want to have their treatments done. Since they think as if there are hidden thing related to their illnesses, as soon as the patients see me, they ask some mind-bending questions such as am I good, why don't you call my family, what does it mean and so on, which makes me overwhelmed and I do not know what to say. Sometimes, even if I make a statement, I do not think they have ever listened to me after a while. It is difficult for them to wear masks and to tear their hands too often. They can give rude answers when we remind of the controls. For instance, they say that what is it up to you, I got it, just go, do you follow me, enough is enough etc. However, they do not give such answers to nurses or doctors.

G8: Patients ask unnecessary questions that are not related to their illnesses and my duties in the clinic. I mostly do not answer those questions or cross them out. At that time, they label me as "a grumpy nurse" and they complain about me to the elder nurses. In this case, we have completely lost the communication with each other. In addition, while taking electrocardiogram, female patients do not want male nurses, or even they do not admit any treatment by male nurses. Gender of doctors is not important for women, but the female patients distinguish between nurses, which creates problems. Some patients do not like the treatment since they think they have lots of information related to the illness. They ask detailed questions, and if they have been treated elsewhere, they make comparisons with it and criticize us. In this case, I deal with my work and leave there without much communication with that patient.

G9: Since they are prejudiced against the intern students, they do not want them to apply any treatment. When I am tolerant to the patients, we do not face any problems. Otherwise, I consult the elder nurses. I'm retreating. Apart from that, I am not having any problems.

G11: I am having communication problems such as rejection of the treatment, questioning of the work which I do or unnecessary requests. I have also some patients with whom I face language problem.

G12: In my policlinic, a fight often arises because of the order of treatment and the patients taking each other's places by not obeying the order. Patients who are older than 65 years have priority, but patients with more urgent conditions object to it. I often have to deal with this confusion in the outpatient clinic. Patients regard everything I try to tell as insulting and we are constantly confronting. When I get inside, they try to complain about me to the doctor. Sometimes they can even make threatening conversations as though I was the guilty of problems related to the system. I'm afraid, and I feel like I'm being followed while going to my house. During the treatment, they calm down and behave very respectfully towards the doctor.

Findings from the interviews show that nurse candidates had experienced almost all of the problems that may be experienced during the internship. Having little work experiences and patients' prejudiced behavior make it difficult for them to understand the communication problems they are experiencing. Nevertheless, they said that they were more easily able to cope with the problems than they were in 11th grade, that they became more encouraged in recognizing and understanding patients, and that they were more confident in themselves because they increased their skills in implementing patient care.

Nurse candidates would improve their self-confidence when they recognize themselves well, be aware of their skills, and will increase their ability to observe and make decisions when they increase their confidence. In addition, even though the nurse candidate was an adolescent, she can assume adult responsibilities, enrich herself with various communications she has established, broaden her horizons, and experience the pace of change faster than her peers. After a while, she may feel the feeling of separation and loneliness from her peers who have shared the same experiences. (Terakye, 1994: 21). There were points to be noted when interfering with difficult or problematic patient behaviors that cause nursing candidates to experience difficulties physiologically and psychologically, which adversely affect the treatment and effective nursing care in clinics. The first one of these points was to recognize a patient as an adult individual who needs help, not an object with an illness. It was necessary to focus on what the patient is actively listening to, what the patient wants to express through oral and nonverbal behaviors. For this, it should be possible for nurse candidates to express themselves by using communication techniques while communicating with the patient. (Goral, 2011: 9). 
In the interviews, it was also determined that nurse candidates were difficult to care for patients who did not speak Turkish. That the language education they got at schools is inadequate, that they were not trained for foreign patient care, that the patients migrating to Turkey do not speak Turkish and that there is either no translator or an inefficient one in the hospitals are the reasons that affect nursing badly. For this reason, it was necessary to make necessary arrangements for adding the concept of intercultural nursing to the nursing curriculum, to provide Turkish education to the people who are taken as refugees to the country, to have interpreters in the hospitals where foreign nationals are concentrated, and to increase the numbers to a sufficient level (Polat \& Akcan, 2016: 13).

\section{How nurse candidates react to the communication problems they experience with patients in clinics}

One of the patient behaviors that nurse candidates see as problems in hospitals was "crying". Adult people are able to control crying behavior, so crying can be viewed as a sign of inability to control weakness and inadequacy. Crying is a form of communication. We can express sadness, despair, suffering, blocking and the need for help through crying. Crying is a sign of a feeling of accumulation. Sometimes, the last event that started crying is just the last straw (Terakye, 1994: 74). A nurse candidate did not try to stop crying, but she rather treated permissively towards it. By observing the privacy, she could take precautions such as ensuring that the patient will be given some space. She could give a handkerchief if the patient needs it. A light touch on the shoulder or silence may indicate that she accepts crying and tears. It was crucial to wait for the crying to end to talk to the patient. When she sees a crying patient, she could reveal behaviors of acceptance, most of which are nonverbal, without saying "do not cry" or "cry if you want to" (Özcan, 2006: 166).

Another behavior that appears to be a problem was "refusing the treatment". Patients sometimes did not accept their dependence as they see restrictions for them. If the service conformation and working plan requires the patients to be remain in their room as much as possible and not to be a part of the service, patients who cannot accept the change of passive habits from an active life to passive life may feel restricted, hindered, inadequate (and so depressed), and they may refuse "the treatment or to cooperate" unreasonably with these feelings, or may harm themselves (Terakye,1994:77).

Despite the patient, nurse candidates cannot do any practice that the patient does not agree to and does not attend. In treatment and care, the patient should be able to cooperate and participate in all decisions about to him / her. Therefore, it is necessary to emphasize the expected behaviors from an adult patient by using and appropriate approach and with positive proposals. Furthermore, emphasizing "what they can do" instead of "what they should not do" increases the likelihood of being obeyed (Özcan, 2006: 169).

The patient's need of information and "language problems" also play an important role in communication. Every patient needs to know about their situations, what doctors thought about themselves, what the disease was, the likelihood of treatment, and in many other aspects, they should be informed. Being informed is also one of patients' rights. Patients who are not sufficiently informed grow uneasiness. The language used while informing should be open and understandable. Especially, when with patients during patient care, to talk in medical terms, not to make enough explanation about the disease, and not to let them ask questions affect patients negatively. Misinterpretations cause them to make wrong comments and increase their anxiety and fear, which constitutes an additional burden on both the patient and the nurse candidate (Özcan, 2006: 186).

The most important feature of "patients with continuous unnecessary wishes" was that the security requirements were not predetermined and were not sufficiently met. The patient was in fear and loneliness. She wants somebody to be there at all times and always talk to her, for which the patient constantly occupies the nurse candidate who he sees nearest, invites him with unnecessary requests, often shouts to force him to come, and he makes his hand in order to hold it for a long time. As long as the unmet needs underlying the patient's behavior are not comprehended, frictions occur. (Ozcan, 2006: 182).

Nurse candidates sometimes worry that this proximity may be misunderstood and misinterpreted by the patient when they were close to him / her, thus stating that they are kept at their distance. The fact that they were inadequate for managing patient behavior has a major role in this situation. Managing patient behavior requires certain knowledge and professional skills. However, it should not be forgotten at all that, whether or not the 980 
patient sees nurses as a "sexual object", it was important to know how and in which position the nurse candidate sees herself. If she never sow herself as such and sow herself as an individual who helps the sick to solve the problems, no one can see her in a different way. Hence, the patient will understand that the message he sends in sexual sense was not perceived in the sense it is sent to and will reevaluate his behavior. (Terakye, 1994: 78)

Nurse candidates have explained with various examples how they behave in the face of the communication problems they have experienced. According to this, the role and effect of empathy in removing the communication barriers is expressed as $(\mathrm{G} 1, \mathrm{G} 2)$ :

G1: I have never been in conflict with patients up to now because of the problems I have experienced. I am aware that that person is also a human being; I try to understand him/her by empathizing. If I do not succeed, I prefer to leave the room and tell the situation to the nurses.

G2: "I try to guess patients' emotions and thoughts empathically. But sometimes I cannot be successful. They are so prejudiced against male nurses that I' become worried about my future. In general, I try to speak politely and explain everything in detail. Although I am successful most of the time, I report the situation to the nurses if it does not help.

S/he expressed the importance of being tolerant to the patients as follows $(\mathrm{G} 5, \mathrm{G} 7, \mathrm{G} 9)$ :

G5: I am often tolerant and moderate. Some of the staffs are very aggressive. To me, they are going so wrong, because at such times, the problems are getting bigger and conflicts are increasing among us.

G7: I often tolerate and respect the behaviors of patients. Patients feel very lonely as it is a non-visitor acceptable clinic. I try to spend more time with them and I talk to them on the condition that they do not infect me. The nurses of the clinic where I work at are very hardworking and they usually have good communication with patients. However, I can observe their imperative speech and insulting behavior to the patients, as well. I am imitating the beneficial aspects.

G9: I'm empathizing and trying to be tolerant. If it does not work, I report it to the nurses.

They said the followings about treating well and approaching with smile to the patients (G8, G11) :

G8: There can be some nurses who act rudely to the patients. I find it wrong. I think whether I would behave the same way or not in the future, but I believe that I can be more patient and cheerful.

G11: I have not found any other solution except empathizing in my two years of study because when you often show your smiles and behave kindly, they try to abuse the goodwill of you and look at you with different eyes. In addition, I am trying to do the administrations accurately so that they might break their habits of prejudice.

In the matter of talking with a positive, appropriate and calm language to the patients, listening to them, taking time for them and explaining something them, they said the followings (G3, G4,G6,G10):

G3: Even though I have tried to talk to them several times. I have never been successful since the patients are prejudiced against the students. I found the solution thanks to elder nurses. They sometimes cannot endure that situation, so they call the security staffs. Patients always feel themselves as justified and they are constantly shouting in order to prove it. Therefore, I prefer to stand clear and stay calm in such situations.

G4: I often observe the attitudes and behaviors of other health personnel. As far as I can see, I find their attitude a bit unkind. In my opinion it is not right. Of course, there are also some medical personnel who speak with a very nice language, listen to the patients and solve their problems. I usually imitate them. I am trying to approach the patients more moderately.

G6 \& 10: I do empathy. I am trying to solve the problems without growing them. Besides, the nurse and doctor of the clinic where I work are very patient. They sort the problems out properly. They explain each 
administration very well so that the patients can understand it. They also give a written prescription describing the dressing that they will do at home. Patients are often satisfied with this. The problems are solved quickly, though. I am imitating them more. There are patients who cannot get results from long-term treatments and leave them. Those doctors and nurses also spend a lot of time talking to them about motivating.

The option of trying to find different solutions for conflicts with patients in their own way is expressed as follows (G12):

G12: As far as I can see, all the personnel have different behavior patterns. When I try to choose positive ones from among those patterns, I try to be like myself and solve problems with my own will. Since there were no other nurses in the outpatient clinic I work at, I have no one to tell some problem. The doctor is not interested in my communication with the patient, anyway. Since there is a lot of patient pressure and sequence out there, I lock the door as soon as I take patient in. I try not to accept other patients but the exact patient's name on the sequence register. I pretend not to have heard the insults, and I usually do not answer.

Nurse candidates often claimed that they demonstrated empathic behavior when faced with problems. Empathy is the ability to grasp someone's emotional state. Today, when it comes to "empathy," it is conceivable that Carl Rogers and his work on the subject, upon which a vast majority agreed. According to Rogers, (1970), empathy is the process by which one looks at the events by putting himself in the place of another person and feeling that person's feelings and thoughts correctly (Cited in. Dökmen, 2003:135).

Travelbee defines "Sympathy" as a feeling of helping people, and if there is not enough sympathy, he states, the patient-nurse relationship cannot be established. According to Travelbee, (1971), nursing is the interpersonal process between two people. The target of the nurse is to help the individual in developing each and every one of the experiences, in the sense that the individual copes with the illness. In order to achieve these goals, some stages such as the first meeting, identification, empathy and sympathy are passed through. Sympathy can be melded with pity. Pity is a human sentiment, but living with the feeling of "what a poor person" does not help anybody else in the opposite sense. Because nurses are busy, it can be defended that they have little time for sympathy and care. "What does a nurse do at the clinic, if she won't care about the patient?" The nature of the relationship that nurses establish is related to what they keep in the foreground while nursing (Terakye, 1994: 112).

Nurse candidates also stated that when they had communication problems with patients, they mostly conveyed the problem to the nurses and they acted by adopting the behavior model that they found positive and effective.

\section{Problems that students experience with other health workers and patients' relatives in the clinics they practice}

Nurse candidates were influenced by many factors such as physical environment, teaching staff, clinical nurses and other members of the health team in the clinics where they practice. Therefore, it was important that these staff be conscious, experienced and professionally equipped and positive role models in order for the implementations to reach their targets (Turan, Tan \& Dayapoğlu, 2017: 171).

Nurse candidates must use this environment at an optimum level in order to earn a competent nurse's identity. However, hospitals were different environments from the outside world where many health professionals, patients, patient relatives, and other support staff are in present. In order to adapt to this orientation, nurse candidates need to acquire clinical skills without violating the rights of patients. However, there could be ethical violations for them in the clinical education process (Aydoğan, 2016: 123).7

Patient relatives were people who worry about their patients, wish to have a moment of health, panic in emergencies, and unlike other times, are more vulnerable and stressed individuals. While they may have had previous hospital experiences, they may have come to the health facility for the first time. They may experience 
fear, anxiety, and excitement in the new environment. Some negative events that they have seen before can cause them to be prejudiced. It is very important to communicate taking the patient relatives' characteristics into consideration, each of which may be different. These reactions must be known so as to communicate well

(Communication in Health module, 2015: 18).

The following are the responses nurse candidates gave to the questions which aim to specify the problems they experience with health workers and patient relatives.

G1: I do not have problems with health workers. I'm just doing my own works. The health workers do not expect any extra work from me. But sometimes there is a problem on determining the patients among themselves. That the patients' relatives ask for extra things (blood pressure, measuring their sugar, asking for pain relief, etc.) may cause problems. To the extent that we can supply with, we indulge in their requests or I convey them to the nurses; however, when I can't meet their demands, they gossip about me, their attitudes are changing right away. Besides, after visiting hours, there are people who resist not evacuating the room. I talk to them mostly without a discussion.

G2: Some nurses are trying to make us do what they have to do. Patient caregivers, even cleaning staffs do the same thing. Being a man is also effective in being exposed to extra work. They lead me to deal with some errands such as serving tea, calling someone etc. I often swallow those in order not to experience any trouble. That my teacher warns and talks to them does not work, either. They think as though I complained about them. When the teacher is absent, they are bombarding me. I am about to graduate; therefore, I can endure this. If the relatives of the patients come across with me first when I go there in order to treat the patients, they feel prejudiced by saying you may hurt or you may not do it. I try to work making them feel safe, if they insist on too much, I'm reporting the situation to the nurses.

G3: They usually get us to take the patient with a stretcher or a chair. However, we should not just be with the patient. At least a nurse should be with us, but they say we trust you and leave us alone. We have difficulties in shedding patients; none of the staff helps people, either. That's why, I'm having back pains. The patient relatives are also very nervous. There's a lot of slang speech I hear. They can't effectively express their problems and desires. They are approaching with direct prejudice and fighting with us. They always want us to be friendly and treat their own patients as if there were no other patients. They do not let us know whether or not the companion will change when they leave. I usually try to be calm and understanding to them.

G4: Sometimes I have problems with the parents of the children who come to the clinic. Some of them don't want me to touch their kids. They have judgments against us. They don't care when I give the training talk, nor do they listen to me. They ask the doctor. Doctors sometimes tell the situation, but the doctors often do not have time for parents to deal with the patients. I also have a language problem with patients with foreign nationality. I'm not having any trouble with the paramedics.

G5: Medical staffs sometimes make requests that are not our mandate, but if they so wish, I do it. Thus, there is no problem for us. The service is very inadequate compared to the number of patients. Patients sometimes remain in the sediment until the bed is empty. They have too many relatives with them. They are all anxious and curious to ask extremely unnecessary questions. I am having difficulties due to the crowd while dealing with the patients. I am trying to get the patient's relatives out of the sickroom, but they are starting to argue with me right away. Even during visiting hours, we can call the security and evacuate the sickrooms.

G6 \& 10: Sometimes, when I have an expectation that I don't have to do, or when I'm misunderstood, I politely refuse that expectation and I get through it without exaggerating. The patient relatives are mostly inconsiderate, they don't want us to treat the patients; otherwise, they can yell at us. They want every procedure done by a doctor. Sometimes, they even stand in the nurses' way. We are trying to do our job with patience, understanding and tolerance. Also, some relatives of patients are constantly complaining to us about their patients. They are asking for help from us, saying, "Tour patients are not doing what is advised by the doctor, they are fighting with me, I cannot cope with the patients." In the policlinic, all the staff is doing their best for them. 
G7: Sometimes, we are asked to help the cleaning staff when the service cleaning is not done until the visit hours. They want us to do the errands and to lie low when the clinic is quiet. Some of the patient relatives are very selfish and curious. They just want us to take care of their patients. They wonder what treatments we're doing to the patients. They dare to account for our work. I think they do not trust on the medical staffs. We are the ones who always behave in understanding and calmness; otherwise, we are aware that any argument may happen.

G8: They are trying to load some work that we are not responsible for doing; even they are seizing our lunch time, somehow. There is a nurse who behaves outrageously to us. Once, I tried to stand up against that nurse, she immediately exaggerated me to blame. I encountered with the danger of being kicked out of the service. They can insult us, for instance, they say that you are getting money here, so you have to do what is said to you. When I encounter with that event, I am badly affected. I am crying and calling my teacher at that time. Patient relatives also see us a prospective bride for their sons. They have a beef with us. They are always curious about us; try to learn about us, as well. I pretend not to hear them and I try to draw their attention to the patients.

G9: I have almost no problems with the paramedics. They are very understanding and protective towards us. Patient relatives cannot enter the clinic because of the risk of infection. Sometimes, if they try to break into it, there are some small problems.

G11: The nurses are expecting much more work than we can do as though they had never been students. They just leave their rooms and leave us alone in the treatments. I once said, "I ca not be sure that the patient's blood pressure is very variable. "You measure very well, do not worry, save it," she replied. There are also secretarial work which is done by the service staff; however, they request us doing those works such us cleaning the treatment table, fulfilling the folders etc.,, which make me amazed how they can trust us anyway. Because I do not want that the patient gets hurt, I do most of the work diligently, and I avoid arguing with someone. I have never seen a patient relative being angry without a reason. If I do not deal with the patients and treat them on time, they can account for it. If we behave in considerate and give confidence, they easily trust us.

G12: When I want to do non-calendar work, when I say "no, I will not do it", they act immediately and complain. Sometimes they apply psychological pressure. They act as if we're not there. Patients were out of the policlinic and the lunch break was approaching. Dr said to me, "Go get me some water from the crotch." I said, "Even if I get it, I cannot come back, I am going to eat somethings". I had to work for another week with the same Dr until the end of the clinic, and he acted as though I was gone. Once I said "good morning" and I did not even get an answer. I've never been able to make it to a doctor.

The importance of clinical practice in the transformation of theoretical knowledge into nursing education and in the development of professional skills of nurse candidates is incontrovertible. In interviews, nurse candidates stated that they had problems with other health personnel such as multiplying their workloads, making irrelevant work, not seeing them as a teammate, applying various sanctions when they objected, and being exposed to insensible and sometimes cruel behaviors. They also stated that they had problems with patient relatives who sometimes acted selfishly as they saw nurses as servants, and who were always inclined to fight if nurses did not act insightfully.

When communicating with the patients' relatives, it should not be forgotten that everybody has different illnesses and illness-related experiences, and no other stories that reduce hopes should be told to them. During this process, listening to their affinity and sharing experiences can be considered the best emotional support. In the treatment process in which the needs of the patient are emphasized, the patient relatives may neglect their own troubles and needs. They may experience problems such as lack of sleep, irregular eating order, stress; therefore; specialist support may be needed. Everyone wants to feel loved, valued, not alone in such a difficult experience, and needs the support of their environment (Communication in Health module, 2015: 19).

Nurse candidates' views on the solution of the communication problems they have experienced 
It is accepted that communication and communication skills play a vital role in nursing education and practice, and ineffective communication is one of the most obstructive factors in the quality and quantity of health care (Özcan, 2006).

In health services, the harmony and integrity between the patient- the staff, the patients' relatives- the staff, and also the staff- the staff are very important in terms of the quality of the service provided. Student nurses in education hospitals should be seen as a member of the health team and their opinions and suggestions should be given importance to the problems experienced in communication. The answers given to the students for this purpose are as follows.

G1: My suggestions; 1-Organize seminars on hospitals where respect for the doctor should be as well as for the nurse. 2- To provide a trusting environment for good communication with patients and to answer all the questions that the patient's relatives have. 3-Hanging hospital rules in each room and making them read. 4-In the vocational courses we take in the school, there must be a lot of practical training in theory. Problems are reduced if we are taught how to deal with the problems we have faced in the hospital instead of unnecessary information and unnecessary vocational courses as the lessons are in the hospital environment.

G2: My suggestions; 1- Everyone has to mutually empathize with each other and understand each other in every way. 2- Patients and their relatives need to break their prejudices against healthcare workers (especially against male nurses). 3- Healthcare professionals should also be more caring, sincere and concerned about the illness. 4- It is necessary to educate both sides about how to communicate between patients and health workers. 5-When we face such problems; we should be trained on where to go and what to do on both sides.

G3: My suggestions; 1-Patients should not regard health personnel as servants. 2-Behavior training should be given to patients and their relatives. 3-Communication lessons should be applied. 4-Very angry patients and health personnel should be trained for anger control. 5- Diseases should be carried out to destroy prejudices against health personnel.

G4: My suggestion is that the psychology of the patient in the hospital should be very well considered and she should be treated with empathy.

G5: My suggestions; 1- Every health staff must first empathize in the communication process. 2- The health personnel should be respectful to the patients' rights and comply with certain rules and be continuously supervised by a responsible person.

G6: My suggestions; I- If I have a language problem with a foreign patient, I should get help from a interpreter. 2- If I have a problem with the relatives of the patient, I should warn them kindly and want them to go out. 3-I should be patient, explanatory and obvious.

G7: My suggestions; 1- Nurses and relatives of patients should not be prejudiced against each other. 2- They should show empathy towards each other. 3-You should be considerate to relatives of the patients and respect to their thoughts. 4- We can encounter with some events that we have never learnt in communication course, so context of that course should be enlarged.

G8: My suggestions; 1- First of all, I must say that the problems never happen unilaterally. Everyone in the hospital is stressed. New reports should be written and read by everyone in the hospital such as hospital management, doctor, nurse, patient, patient relatives etc. They should sign for accepting the report. Inservice trainings and conferences often should be given.

G9: 1- As we nurses, we are doing most of the tasks because we have a communication with the patients most period of the time. We should show more tolerant, empathic and respectful manners to the patients' ideas. The courses we take are not enough, they just depends on memorizing. after a while we are completely forgetting what we learned. We have to take communication courses every year. We must process all problems realistically and practically in a broader context. 
G10: My suggestions; 1-We should not misjudge and judge the patient's thoughts and concerns. 2. We should listen to the patients more carefully and try to understand them by showing our empathy. 3- We should not be prejudiced against the patients. 4- We should behave respectfully to them and save their rights.

G11: My suggestions; 1- We have courses such as Communication in Health Services, Medical Ethics, Psychology, Mental Health and Psychiatry. However, while the theoretical knowledge is forgotten until the exam day, and things learned by experiencing are not forgotten. We should teach the lessons more comprehensive and practical. We should take lessons from our past so that we could develop our relationship with the patients positively. 2- First of all, we should not forget that no one comes to the hospital unless they are obliged, nor do they not sleep in the clinic. Patients need healthcare and especially nurses' compassion and interest. We should exhibit modest, cheerful, sympathetic, and positive behaviors. 3-Doctors should not distract the patient, they need a solution-oriented approach to their treatment. They need to believe that they cannot treat without the nurses and treat them more respectfully.

G12: Firstly, I think that we must communicate by giving consideration to patient psychology and giving priority to their thinking. The solutions are not expected from just the nurses, everyone should carry out what to do.

It was evident that students stated that they should first empathize while solving problems they experience, that the lessons they see during the training reflect realistically the problems and apply them, that the patients do not see nurses as servant and they should show them the respect they show to the doctors as well, that the doctors should also be more respectful to the nurses, and that mutual-healthy communication techniques should be given very frequently to all sides through in-service trainings.

\section{A problem that nurse candidates have either observed or experienced, which affects them the most}

In this section, experiences chosen from nurse candidates' statements were described in the most realistic way and tried to be given as case studies.

G1: Last year, when I started to work at the hospital, they said me to draw blood from a patient in the Cardiology-1 Service. There were a 40-year-old man, a girl who might be my peer, some nurses and the interns with me. Ifound the patient's vein, when I draw blood, my hands thrilled. Then, the patient's daughter screamed and walked up to me but other staffs hindered her. She said how a bad nurse she is; she cannot draw blood from my father etc. I was very frightened and excited. At that time, my teacher came, too. Together with the nurses, they tried to calm the patient relative. The patient was affected by this situation, as well. The patient wanted the nurses to draw his blood and I left the room crying. I could not draw blood for a while after the event and I realized that I had not given the proper information to both the patient and the relative of him, nor I did give any confidence. However, I took lesson from that experience; afterwards, when I came into the sickroom, the thing that I did at first was taking the patient relative out of the room.

G2: I had a problem with a 40-year-old female patient while practicing in the gastroenterology service. The patient was diagnosed with stomach cancer. She was in bed and was being monitored closely by the doctors. The vital findings such as blood pressure, heart rate, and fever were being measured every hour. When I measured her blood pressure, it was 100/70 mmHg. After I had said the result to her, she started to shout at me. "I am high blood pressure patient, the result has never been so low like that, you have measured my blood pressure wrong. "she said and other patients in the room supported her speech.

I never answered, I immediately left the room and called the nurse. When second nurse measured it, the same result came out, but we called third nurse to make the patient sure got the same result and she was convinced at the end. The nurses said to the patients that that intern student is the most hardworking one, if we do not trust her; we will not allocate responsibility to her. Finally, the patient apologized from me, but I did not go there again because I was afraid of facing the same situation again.

I encountered with the same event with a male patient too. When I went to the clinic, the patient did not believe that I am a nurse because she was thinking the entire nurse should be female. I told the situation to the female nurse, they treated that patient instead of me. 
G3: A 50-year-old woman who has heart disease said me that if you hurt me, I will beat you, be careful. I was surprised hearing this. After drawing her blood softly, I came up with an explanation that we are just doing our work; you should not talk to any paramedic like that. She again said me that you are younger; it was just a warning to the interns. There is an attitude in the hospital that patients can tell what they want to the interns.

G4: While interning in the emergency hemodialysis unit, we had a 4-hour dialysis of a patient. The patient was fainted on the way, and those who saw him brought him to the hospital. The patient was dialyzed without any problems at first, but he said that he wanted to leave in a rude way for the last hour. The nurses in that service told the man, if he had left here without completing the whole treatment, it would be harmful for his health, but the patient did not care about the warnings, shouted at the medical staffs and he also cursed. That's why; the nurses finished the treatment and sent the man. I think that if they had tried to understand each other and had explained their situations well, maybe that kind of event would not have happened.

G5: I was going to administer intravenous fluids to the patient. I adjusted the flow rate of the drug. Only 5 drops per minute were needed, and this could cause sudden death of the patient if the fluid flows fast. I told the patient and the patient relatives many times about the importance of the situation. I told them never to play with the serum. I was influential in myself, and I thought they wouldn't do that. 10 minutes later, when I was getting out of another sickroom, I heard that the patient relative was saying to the nurse that that serum was over. We were surprised; we went to the sickroom to understand the situation. We realized that the patient had changed the serum cramp. The relatives of the patient were constantly blaming the patient. The patient was saying how I can wait for finishing it. The assistants and nurses came immediately, they removed the patient's relative and they provided immediate treatment to the patient. I thought I would have done this before. Fortunately, nothing happened to the patient. I was relaxed but it has been an experience I would not forget for a lifetime. I have learned that the patient and the patient will never be trusted in such an important treatment. When she saw that I was very scared, the nurse said, "Do not be afraid, do not lose confidence, the result is satisfactory, but be more careful after that because you are an intern, nothing happens to you, but we can have a trouble then.

G6: When I was working at intensive care unit, a male patient's forebrain lobe had been taken out. He was making trouble during the treatments, he did not want be touch by anyone, so I could not inject to him. I was a bit afraid of him. The nurses came and kept his body tight so that they could apply the treatment. I do not know whether it was a proper behavior or not, but I think it was the easiest way of treatment. If the patient had been given full confidence and approached with compassion to him before the surgery, I think he would not have forced us so much. It have been 6-7 months up to now, I cannot treat the patients in that case.

G10: When we administered quad bandage to the patient who had venous insufficiency, he was constantly in trouble, criticizing the bandage we made. When we checked, he said that the bandage was tight. We tried a lot to convince the patient. He went away, though not very convinced. After 5 minutes, I tried to get in the other sickroom while I as treating another patient. We took the patient in, checked the bandage for relief, and talked to him more clearly, and then he had made sure of the dressing and went to his room. I learned that the tone of speech and the way of speech are very important in communication. I think it is necessary to apply this method in difficult cases.

These experiences of nurse candidates were more related with clinical practice, which enabled them to practice many applications by learning the form of communication and behavioral roles. Nurse candidates have learned how important it was to be more careful when applying treatment and to make an effective explanation to the patient (G5), that they will be more beneficial to the patient with correct and positive communication when they meet with difficult patients (G1, G2, G3, G10), and not to take role models their future fellow colleagues' misconducts (G6) in this way. The events that nurse candidates who were taking a new step towards adulthood at the end of the adolescence period have had a great impact on them. When they were in business, these experiences will make them more responsible and cautious.

Clinical practice areas enable nurse candidates to observe role models, take responsibility, practice according to the patient's clinical chart, make decisions and work as a team member. The clinic gives students the opportunity to learn and practice by practicing the theoretical knowledge learned in the school environment in 
real environment. It also helps them to observe that different professions work together in harmony and to be part of that harmony. While it provides them self-confidence and being well-equipped when they participate in clinical practice, it also minimizes their mistakes in the applications on the patient (Özcan, 2006: 238).

Clinical teaching provides nurse candidates with psychomotor skills and intellectual learning, problem solving, effective use of time, professional decision-making skills, and creative skills. In education \& research hospitals, it is the practice of one person (the candidate) to practice on another (patient) in order to gain psychomotor skills. In this context, there was a high probability that ethical problems will be faced in these kinds of environments, where both education and treatment and care of patients were made. Ethical problems may be experienced as ethical violations towards patients and students and ethical dilemmas. The patient was the party demanding care, and the nurses are the party holding the care giving power. Therefore, this situation can imply that the patient is dependent on the nurse herself. As a result, patients were forced to comply with rules that require them to act in a dependent manner. One such practice is for nurse candidates to be trained, in order for the clinic workload to be lessened and to show the patient as if the treatment was obligatory when he / she refuse it. In this case the patient's autonomy is left behind G2: "Older nurse sisters said "she was the most hardworking student of the service, we wouldn't leave it to her if we didn't trust her."

The reason for this practice may be that the nurses see the benefits of the students as superior. Maybe they are not even aware of the autonomy of the patient. By taking such an action, the nurses may want to reduce their workload and provide benefits them. Because the nurse candidate is more inexperienced than the nurses, on the other side, while taking care of the patients' interests, there is a risk of harm to the patients. For example, it has been many times in hospitals that the candidate be anxious and excited during the application on a patient who has been intramuscularly injected. G1: "I've detected the vein of the patient, just as I was getting it right, my hand trembled and the patient's daughter suddenly started screaming ". When the patient notices this, he wants a more experienced nurse to do it G1: "The patient was influenced by this situation and said," Let the nurse get it. I left the room crying. I didn't draw blood for a while." The nurse, considering the benefits of the nurse candidates, generally applies the method of persuading the patient and allows the nurse candidate to do the application. She also had the risk of making a mistake because she was excited. The patient may develop a complication due to this mistake, or the candidate may harm herself. For example, after injection, the needle can cut into her hand. Teachers and clinical nurses should always be there for nurse candidates to avoid such problems. When nurse candidates are practicing, nurses should be constructive and supportive rather than pressuring on the practice, and should communicate effectively, reducing the anxiety of the candidate (Aydoğan, 2016).

Since 2007, male students have started to be accepted to nursing schools again. The existence of men in nursing, which is known as women's profession, is a situation that society has not yet embraced. For this reason, male nurse candidates are sometimes discriminated against by patients and their relatives. G2: "I also experienced a similar case with a male patient. He said "Is there even a male nurse? You are not a nurse, you are a technician, don't touch me!" It was thought that this will be taken over in time with the increase in the male nurses in application areas. It should be ensured that clinical education can provide expected contributions, that the fields of practice in clinics be regulated for the benefit of nurse candidates and that patient and patient relatives training also be effective (Ergöl \& Kürtüncü, 2013: 65). Because, nurse's in-service trainings and patient and close relatives trainings are adult education and the principles of adult training apply (from Ay, 2007 act: Ergöl \& Kürtüncü, 2013).

Adults should be willing to learn for themselves. Their self-confidence should not be impaired during learning activities. Adults have personal concerns and need a safe environment (Gökkoca, 2001 cited in: Ergöl \& Kürtüncü, 2013). However, violence in the workplace that causes psychological problems such as loss of selfesteem and self-esteem in individuals, irritability and lack of attention is an important issue in the healthcare sector, which is the field of application for nurse candidates (ILO, 2002 cited in: Ergöl \& Kürtüncü, 2013:69).

\section{Conclusion, Discussion and Suggestions}

The profession of nursing was still trying to prove itself medically in our country. However, though the medical model focuses on organs or system diseases, the issue that the patient care requires effective communication does not take up much space. While the nurse has an intensive interpersonal communication 988 
with the individuals she serves, the orientation usually refers to the medical procedures that are related to the patient's illness. There were many successful nurses who had developed themselves medically. These people can provide the patient with good physical care, but due to many reasons, it is not always possible to treat the patients considering their mood. However, most of the complaints of the patient and his family are related to the forms of interaction and communication between the people. The reciprocal negativities among the patient, relatives, nurses and young nurse candidates are due to the fact that their communication skills of nursing care was not developed as much as the physical medical care skills (Özcan, 2006: 16).

That nurse candidates must be aware of their interaction with the people they care for, was required for the professional patient care they will give when they are soon to be employed in the profession. This feature was also a process that determines the quality of professional practice. For this reason, candidates need to deliberately examine and improve the quality of their communication with the patient.

In this study, communication problems between nurse candidates and patients, relatives and other health personnel were identified and named. Besides, the problems that nurse candidates have experienced only in the interviews were not determined, and their suggestions for solution of these problems were also found important.

Nurse candidates have faced more consciously with the communication problems they have experienced through interviews, have become aware and have expressed their desire to become helpless after converting the experiences they have experienced into knowledge and solutions. It is expected that they will also include communication skills in the plan when planning patient care in their future professional lives.

Younger candidates who have not earned the status of an adult yet serve most of the sick individuals to whom they serve and find evidence that they do not yet fully develop self-development and self-recognition processes, nor do they have adequate knowledge of the developmental stages and education of adults.

Younger candidates who have not yet grown up to be adult individuals mostly serve adult individuals, and the findings of the research show that they do not yet fully develop self-development and self-recognition processes, nor do they have sufficient knowledge of adult developmental stages and education. While taking health education, they transfer their theoretical knowledge only by taking the behaviors of clinical nurses as an example together with their own short experiences.

Nurse candidates have experienced problems with their patients in hospitals such as crying, grieving, language problems, unnecessary requests, harm to the environment, expulsion from the room, inadequate hygiene, sightings like sexual objects, prejudices, which they tried to cope with by informing the nurses. Their experiences increased as the length of the internship extended, and factors such as listening and understanding the patient and increasing the ability to care increased their confidence.

While they have problems with unnecessary and irrelevant workloads, ruthless and disrespectful behaviors with other health personnel, they have also experienced problems such as being seen as servants, selfishness and aggressive behaviors with patients' relatives.

While practicing medical treatment during the clinic internship, some of the events that occurred in time to be seen as routine, ordinary and normal behaviors were understood by the nurse candidates to be important and absolutely necessary communication mistakes that have to be solved, and they have come to a conclusion that they have realized important things through experiencing.

It was understood that the communication lessons they received during the training were not very effective in clinical practice because they were more theoretical, they did not fully reflect real events and experiences, and because adult education concepts and techniques were not included.

Although there were no indicators and data related to the economy within the scope of the research, and health communication and economic relations are not reflected; it can be said that there was a high level of significance relation between health communication and health economics. It was clear that the communication problems experienced in the hospitals delay the duration of the treatment and recovery as the patients increase 
their anxiety and fear and refuse the treatment. Thus, the length of hospital stay will be longer and the frequency of referral to the hospital will increase, which will increase the health care expenses of the government. Nevertheless, if a good quality health education programs were provided to individuals by using positive communication techniques for effective, preventive and early diagnosis where adult education techniques were applied in primary health care services before coming to secondary health care hospitals, it can be predicted that a considerable amount of savings will be provided in the share of health that Ankara has allocated for health services.

It was advised to conduct research in a broader sample of nursing and medical education schools, to organize trainings to develop problem-focused coping and communication skills for nurse candidates, to open a new course under the name of adult education in all educational institutions that provide health personnel or to include adult education subjects in the scope of related courses, to continue providing the education of effective communication techniques, to add topics that improve effective listening, comprehension and empathy skills in accordance with the educational levels of patients and their relatives. 


\section{Yetişkin Eğitimi Açısından Hemşire Adayları İle Hastalar Arasındaki İletişim Sorunlarının Değerlendirilmesi}

Giriş

Son yıllarda iletişim üzerinde önemle durulmaktadır. Çünkü iletişim, kişilerarası ilişkilerde anahtar görevi görmekte ve kişilerarası süreçte zaman zaman iletişimi zorlayan durumlar yaşanabilmektedir. İletişim ve iletişim becerilerinin, hemșirelik eğitiminde ve uygulanmasında yaşamsal bir rol oynadığı ve sağlık bakımının nitelik ve niceliğinde engelleyici faktörlerin başında etkisiz iletişimin geldiği kabul edilmektedir (Özcan, 2006:98).

Kron (1966), hemşirelik okullarını ve sağlık kurumlarını, otorite ve gücün tepede toplandığı kurumlar olarak tanımlamıştır. Kron'a göre hemşireler, fedakar, alçak gönüllü ve başkalarına hizmet eden kişiler olup düşünce ve duygularını söylemeleri pek istenmez. Hizmet edecek bir rol için hazırlanırlar. Sağlık ekibinin bir parçası olmaları beklenir, ama karar mekanizmalarında yer alamazlar. Öylesine meşgul olmaları sağlanır ki, haklarını bile gözetemeyecek duruma gelirler (Kron, 1966 dan akt; Özcan, 2006).

Hemşire yetiştiren okullardan, öğrencinin özgüveninin yüksek olması, kendi kararlarını verebilmesi, yaptı̆̆ uygulamayı bilerek yapması, bunaltı, çaresizlik ve yorgunluktan doğan öfkeyi hastalara ve onların yakınlarına yönelterek iletişim çatışmalarına neden olmamasına yönelik eğitim verilmesi ve bu doğrultuda öğrencileri yüreklendirip cesaretlendirmesi beklenir. Hemşire adayları, Beceri Eğitimi ve Staj yaptıkları sağlık kurumlarında meslektaşlarından da böylesi destekler aldıkları takdirde, birey ve meslek üyesi olarak kendilerini geliștirecek ve doğru hedef ile çözüm yöntemi belirleyerek hastalarla yaşadıkları sorunları çözümleyebileceklerdir (Özcan, 2006).

Sağlık kurumlarında, 11 ve 12. sınıflarda haftada 3 gün 8 ' er saat Beceri Eğitimi yapan Anadolu Sağlık Meslek Lisesi Hemşirelik Bölümü öğrencileri de klinik çalışmalarda bakım uyguladıkları yetişkin hasta bireylerle birçok iletişim problemi yaşamaktadır. Bu da sağlık hizmeti sunumunda ve alımında sorunlara neden olmaktadır. Bu araştırmada Anadolu Sağlık Meslek Lisesi 12. sınıf öğrencisi bir grup hemşire adayının, staj yaptıkları kliniklerde hasta bakımı hizmeti ve ihtiyaçlarına göre hastalara hasta eğitimi ve sağlık eğitimi hizmeti sunarken karşılaştıkları güçlükleri, yetişkin hastalarla aralarında yaşanan iletişim çatışmalarını ve yaşadıkları sorunları, kendilerinin görüşleri doğrultusunda belirlemek ve bu sorunları yetişkin eğitimi açısından değerlendirmek amaçlanmıştır. Bu amaç doğrultusunda aşağıdaki soruların yanıtları aranmıştır.

1- Katılımcıların demografik özellikleri nelerdir?

2- Hemşire adaylarının çalıştıkları kliniklerde hastalarla yaşadıkları sorunlar nelerdir?

3- Bu sorunlar ne tür iletişim çatışması yaratmaktadır?

4- Yaşadıkları sorunlar karşısında neler yapmaktadırlar?

5- Hasta yakınları veya diğer sağlık çalışanları ile de sorun yaşamakta mıdırlar?

6- Yaşadıkları sorunların çözümüne ilişkin önerileri var mı?

Bu araştırma, 21 Nisan - 09 Haziran 2017 tarihleri arasında, Ankara Numune Eğitim Araştırma Hastanesinde Beceri Eğitimi yapan dokuz, Ankara Yüksek İhtisas Eğitim Araştırma Hastanesinde Beceri Eğitimi yapan üç öğrenci olmak üzere toplam 12 hemşire adayı ile yarı yapılandırılmış görüşme formu kullanılarak yapılan görüşmelerden elde edilen bulgu ve görüşlerle sınırlıdır.

\section{Yöntem}

$\mathrm{Bu}$ çalışma nitel bir araştırma tekniği olan yarı yapılandırılmış görüşme tekniği kullanılarak yapılmıştır. Yarı yapılandırılmış görüşme tekniğinin araştırmacıya sunduğu en önemli kolaylık, görüşmenin önceden hazırlanmış görüşme protokolüne bağlı olarak sürdürülmesi nedeni ile daha sistematik ve karşılaşılabilir bilgi sunmasıdır. $\mathrm{Bu}$ yönüyle eğitim bilim çalışmalarına daha uygun bir araştırma biçimidir (Yıldırım ve Şimşek, 2005)

\section{Çalışma Grubu}

Bu araştırmanın çalışma grubunu MEB Anadolu Sağlık Meslek Lisesi Programı, Hemşirelik Bölümü, 12. sınıfta öğrenim görmekte olan ve Ankara Numune Eğitim ve Araştırma Hastanesi (ANEAH) nde ve Ankara 
Yüksek İhtisas Eğitim ve Araştırma Hastanesi (AYİEAH) nde haftada 3 gün 8' er saat beceri eğitimi yapan 12 hemşire adayı oluşturmaktadır.

Adayların12. sınıflardan seçilmiş olmalarının nedenleri şunlardır:

11. sınıfta da haftada 3 gün 8 er saat beceri eğitimine çıkmış olmaları ve yaz stajı yapmaları. Ayrıca mesleğe atanmalarına kısa bir süre kalmışken hastalarla yaşadıkları iletişim sorunlarıyla yüzleşip, farkındalık kazanmaları ve çözüm yolları üreterek gelecekte daha bilinçli ve profesyonel bir etkileşim kurmalarıdır.

Araştırmanın adı geçen hastanelerde yapılmış olmasının nedenleri şunlardır:

1- $\quad$ Ankara Numune Eğitim ve Araştırma Hastanesi, 1800' lü yıllardan beri hizmet veren, Ankara'nın en eski sağlık kuruluşu olup, günümüzde personel sayısı, hasta sayısı, tedavi ve bakım başarısı, hasta ve hasta yakınlarının sosyolojik, psikolojik ve kültürel özelliklerinin Türkiye mozaiğini tam olarak yansıtması, vaka çeşitliliği ve aynı zamanda eğitim hastanesi olması sebebiyle öğrencilerin teknik bilgi, beceri, görgü ve deneyimlerini zenginleştiren bir kurumdur. Bu hastaneden, 1 erkek, 8 kız olmak üzere toplam 9 hemşire adayı ile ile görüşme yapılmıştır.

2- Ankara Yüksek İhtisas Eğitim ve Araştırma Hastanesi, Ülkemizin en büyük Özel Dal Hastanelerinden birisi olup 50 yılı aşkın bir süredir, özellikle Kalp Damar Cerrahisi Alanında, büyük başarılar göstermiş kadrosuyla ekip çalışmasına iyi bir örnektir. Hemşire adayları bu hastanede mesleki açıdan kendilerini geliştirebilmektedir. Bu hastaneden de 1 erkek, 2 kız olmak üzere toplam 3 hemşire adayı ile görüşme yapılmıştır.

\section{Veri Toplama Araçları}

Görüşmeler 21 Nisan - 09 Haziran 2017 tarihleri arasında,staja çıktıkları günlerde, işlerin daha az yoğun olduğu öğlen ve akşam saatlerinde, hemşire adaylarının çalıştıkları kliniklerin sorumlu hemşirelerinden izin alınarak yapılmıştır. Adaylara, görüşme protokolü ve 7 sorudan oluşan görüşme formu oluşturulmuş, her biriyle $15-25 \mathrm{dk}$ aralığında rahat ve serbest yanıtlar vermeleri amaciyla bireysel görüşme yöntemine uygun görüşmeler yapılmıştır.

Görüşme sırasına göre görüşmeciler G1,G2 şeklinde sırasıyla numaralandırılmışlardır. Tüm görüşmeler, karşıllkklı ve etkili dinlemenin gerçekleştiği, samimi, güvenilir ortamda, görüşme protokolü okunarak gerçekleşmiş olup verilerin daha sağlıklı bir şekilde tutulabilmesi için ses kayıt cihazına kaydedilmiş̧ir.

Araştırma verilerinin çözümlenmesinde betimsel analiz tekniği kullanılmıştır. Betimsel analiz; elde edilen verilerin daha önceden belirlenen temalara göre özetlenip yorumlandığı, görüşülen bireylerin görüşlerinin çarpıcı bir biçimde yansıtmak amacıyla sık sık doğrudan alıntıların kullanıldığı ve elde edilen sonuçların neden sonuç ilişkileri çerçevesinde yorumlandığı analiz tekniğidir (Yıldırım ve Şimşek, 2005)

Görüşme kayıtları yazılı hale getirilmiş, elde edilen veriler araştırma soruları çerçevesinde yorumlanmıştır. Bununla birlikte verilerin betimsel çözümlemesinde görüşme yapılan öğrencilerin görüşlerini yansıtmak amacıyla sık sık doğrudan alıntılara yer verilerek elde edilen bulgular düzenlenmiş ve yorumlanmış bir biçimde sunulmaya çalışılmıştır.

Hemşire adaylarının görüşleri gizlilik esasına dayanılarak isimleri verilmeden kodlanarak aktarılmıştır. Buna göre her görüşme " $G$ " olarak kodlanmış, görüşme sırasına göre her adaya " $G 1, G 2, G 3, G 4, G 5, \ldots G 12$ " şeklinde bir numara verilmiştir.

\section{Bulgular ve Yorumlar}

Araştırmanın bu bölümünde, görüşme formunda yer alan sorular problemlere göre gruplanmış ve bulgular sunulmuştur. Hemşire adayları, demografik olarak benzer özelliklere sahip olmakla beraber, yaşları 17 ile 19 arasında değişmekte ve 2'si erkek 10'u kızdır. 12. sinıfta öğrenim görmekte ve 2 yıldır hastanelerde haftada 3 gün 8 'er saat beceri eğitimi yapmaktadırlar. 


\section{Hemşire adaylarının görüşme sırasında beceri eğitimi yaptıkları klinikler ve bu kliniklerde tedavi olan hastaların demografik bilgileri}

Hemşire adaylarının yüz yüze geldiği her yetişkin hastanın kendine özgü yönleri vardır. Her hasta bireyin kendini, yaşını, hastalığını, hastanede yatışını ve uygulanan tedavileri algılayışı farklı olduğu için, bunlara göstereceği tepkilerde farklı olacaktır. Bireyi tanımak için hemşire adayının önce bilgi toplaması gerekmektedir. Bilgileri, hastanın dosyasından, hekiminden, diğer hemşirelerin gözlemlerinden ve hastanın yakınlarından dolaylı olarak veya hastalarla kurduğu kişilerarası ilişki boyunca hastayla doğrudan etkileşime girerek, gözlemleyerek ve ipuçlarını değerlendirerek doğrudan toplar (Özcan, 2006).

Hemşire adaylarından G1, G2, G7 ve G11, Hastanelerin Dahiliye Kliniklerinde (Kardiyoloji, Gastroenteroloji, Hematoloji, Genel Dahiliye), G3, G8 ve G9 Cerrahi Kliniklerinde (Üroloji, Genel Cerrahi, Göğüs Cerrahisi), G5, Acil Tıp Kliniğinde, G4, G6, G10 ve G12 ise çeşitli Polikliniklerde (Çocuk, Kronik Yara, Karaciğer Safra) staj yaptıklarını söylemişlerdir.

Hizmet sundukları hastaların demografik bilgilerine yönelik olarak da G4 dişındaki tüm adaylar 35 - 45 yaş aralığında ve çoğunlukla erkek hastalarla karşılaştıklarını belirtmişlerdir. G4:” Yenidoğandan başlayıp 17 yaşına kadar olan çocuklar geliyor. Kız erkek oranları aynı” demiştir.

Hastaların eğitim durumlarını G2: "İlkokul mezunu çok olmasının yanında hiç eğitim görmemiş hastaların da fazlaca olması dikkatimi çekiyor", G7: "En çok ilkokul mezunu, ama lise ve üniversite mezunlarının sayısı da az değil" şeklinde belirtirken, diğer adaylar hastaların çoğunlukla ilkokul mezunu olduğunu ifade etmişlerdir.

Hemşire adaylarının ifadelerine göre bulgular göstermektedir ki, farklı kliniklerde staj yapmalarına rağmen, karşılaştıkları hastaların büyük çoğunluğu yetişkin, erkek ve ilkokul mezunu bireylerden oluşmaktadır.

Görüşme devam ederken "Bu yaş grubundaki yetişkinlerle iletişim kurmakta güçlük çekiyor musunuz" sorusu yöneltildiğinde adaylardan; G3 ve G9: “Genel olarak, anne, baba, akrabalar gözümün önüne geliyor, onlara davrandığımız gibi yaklaşmak istiyorum, fakat hastanın şımarmasını istemiyorum, özellikle erkek hastalar tarafindan yanlış anlaşılmaktan korkuyorum, beni önemsemez diye düşünüyorum, mesafeyi ayarlayamamaktan korkuyorum, iletişimi başlatmakta bazen güçlük çekiyorum” gibi yanıtlar vermişlerdir. Bu hemşire adayları (G3, G9) yetişkinlerin gelişim dönemlerine özgü davranış özellikleri konusunda yeterli bilgiye sahip olmadıkları, kendini tanıma sürecinin henüz tam gelişmediği ve benlik gelişimlerini de meslek ilişkisini yeterince kurmaya yönelik olarak henüz tamamlamadıkları düşünülmektedir. Diğer 10 aday ise iletişim kurmakta zorlanmadıklarını ifade etmişlerdir.

\section{Hemşire adaylarının, hasta bakımı hizmeti sunarken karşılaştıkları iletişim sorunları}

Sağlık kurumlarında yaşanan ve iletişimi engelleyen zor durumlar hekim, hemşire ya da hastadan, hastalıktan, tedavinin başarısızlığından, sağlık sistemindeki sorunlardan ve sosyal destek yetersizliğinden kaynaklanmaktadır. İletişimi engelleyen davranışları olan hastalar genellikle "zor hasta" veya "problemli hasta" olarak tanımlanır (Macdonald M. 2003, akt: Göral, 2011). Yapılan çalışmalar göstermiştir ki 20-40 yaş arası, işsiz, eğitim seviyesi düşük, kişilik bozukluğu olan ve çoğunlukla erkek hastalar zor hastalardır (Koekkoek B., Meijel B., Hutschemaekers G. 2006, akt: Göral, 2011). Ayrıca, zor hastalar daha çok içe dönük, sürekli istekleri bulunan, ikincil kazanç sağlama amacında olan, agressif, tehlikeli, ilgi bekleyen, ağlayan işbirliği yapmayan, sözel iletişim kurmayan, kural tanımayan, anksiyetesi yüksek, yalan söyleyen, korkmuş, inatçı, kafası karışmış, baştan çıkarıcı, kırıcı, açıklanamayan semptomları (hastalık belirtisi) olan, hijyeni kötü olan, bakım ve tedavilerine uymayan, hastalıklarını inkar eden hastalar olarak belirtilmiştir. Ayrıca zor hastalar en çok, cerrahi, kardiyoloji, pediatri, geriatri, psikiyatri, onkoloji klinikleri ve acil servislerde görülmektedir (Wolf Z.R., Smith G.R.,2007:akt,Göral, 2011).

Hemşire adaylarının, hizmet sundukları hastaların, yaş grupları, çoğunun erkek olması, staj yaptıkları klinikler açısından zor hastalarla karşılaşmaları ve iletişim sorunu yaşamaları kaçınılmaz gibi görünmektedir. Sorunlara ilişkin hemşire adaylarının yanıtları şöyledir. 
G1: Çalıştı̆̆ım klinikte hastaların kalp hastası olması ve uzun süre hastanede kalmaları sorunları arttırıyor. Çok endişeliler, kaygllılar. Işlem yapmaya gittiğimde çok sert tepki veriyorlar. Sen git, hemşire gelsin, bana dokunma gibi ifadelerle bağırıyorlar. Bütün hastalar aynı şeyi yapmasa da genellikle erkek hastalardan aynı tepkileri alıyorum. Hastalar sürekli geziyor, bu yapacă̆ım tedavi saatlerini aksatıyor. Çıkıp aramak zorunda kalıyorum. Tedavi ve bakım zamanlarına itiraz ediyorlar ve tedaviye karşı çıkıyorlar "daha yeni yapmıştın iğnemi, yine mi tansiyon ölçeceksin”gibi ifadeler kullanıyorlar. Bazen oral yoldan vereceğim ilacı koridorda gezerken içirmek zorunda kalabiliyorum.

G2: Çok fazla iletişim problemi yaşadı̆̆ım söylenemez. Ama bazı hastalar, hastalıkları ve hastane psikolojisinden dolayı sorun yaratabiliyorlar. Uygulanması gereken tedaviyi reddediyorlar. Erkek olduğum için birçok uygulamayı bana yaptırmak istemiyorlar, "senin elin ağırdır çok acıtırsın" diyorlar. Bazıları hemen iyileşmek istiyor, sıkıntılar uzun sürünce de sinirlenip bağırıp çă̆ırarak, küfürler sarfederek, serum setini söküp atarak, ăglayarak, davranış bozukluğu gösterebiliyorlar. Tedaviyi yarım bırakıp hastaneden gidenler de oluyor. Hemşirelere, özellikle de ögrenci hemşirelere karşı çok önyargllılar. Doktorları gelince daha sakin ve saygll oluyorlar.

G3: Bizim serviste problem yaşamamak mümkün değil. Hastalarda bize karşı çok fazla ön yargı var. Erkek hastalar fazla oldukları için aşırı sinirliler. Bazen ağrllara dayanamayıp çığlıklar atıyorlar. Bu beni çok endişelendiriyor. Hemen yanlarına gitmek istiyorum, fakat hemşire ablalar engelliyor. "Ağri kesicisini yeni yaptık, dikkat çekmeye çalışlyor şimdi geçer ă̆rısı, susar” diyorlar. Ne gariptir ki doktoru görünce de "ă̆rım azaldı çok iyiyim” diyorlar. Gereksiz isteklerde bulunabiliyorlar, örneğin, "sigaran varmı? bana sigara bul, canım kebap istedi ziyaretçim getirecek sorun çıkarmayın” gibi. Tedavi saatlerinde yerlerinde durmuyorlar. Saatleri kendilerine göre ayarlamak istiyorlar. Özellikle bizim işlerimize sürekli müdahale ediyorlar. Bazen erkek hastaların bakışları, tavırları ve sözlerinden beni cinsel obje olarak gördüklerini zannediyorum. Ama ögretmenlerimin telkinlerini ve hemşire ablaların davranışlarını örnek alarak kolay atlatıyorum. Son zamanlarda yabancı uyruklu hastalarımızda oluyor. Onlarla da dil problemi de yaşlyorum.

G4: Çok sık olmasa da zaman zaman problem yaşıyorum. Çocuk polikliniğinde çalıştığım için hasta yakınlarıyla daha çok yaşıyorum. Çocuklar muayenede dr a ve bana zorluk çıkarıyorlar. Poliklinikte ayrıca bir hemşire bulunmadı̆̆ından teskin etmek dikkatini başka yönlere çekmek bana kalıyor. Ĕger yabancı uyruklu ise işimiz iyice zorlaşıyor. Çocuklar çok korkak ve ajite oluyor. Ayrıca, hijyeni çok bozuk çocuklar gelebiliyor. Yakınlarına eğitim vermek gerçekten çok zor oluyor.

G5: Hastalarla iletişim problemi çok yaşamıyorum. Bizim serviste hastalar çok uzun tutulmuyor, sirkülasyon çok fazla acil müdahaleleri kontrolleri yapılıp diğer kliniklere ve hastanelere gönderiliyor. Servis çok kalabalık hasta yakınları çok telaşlı ve sinirli onlarla daha çok yaşıyorum.

G6 ve G10: Hergün 10 hastadan en az 3'üyle problem yaşıyorum. Çok stresli ve yoğun bir poliklinik. En çok karşılaştı̆̆ım problem hastaların önerilen tedaviye uymaması. Dr un verdiği ilacı kullanmama, evde yara bakımını düzenli yapmama. Söylenenleri yapmadan kontrole geliyorlar, iyileşme gerçekleşmediği için tedavileri uzuyor, bu seferde beklentileri yerine gelmiyormuş hissine kapılıp öfke saçıyorlar. Il dışından gelen çok hastamız var. Yatarak tedavi görecekleri yatak sayısı çok az olduğundan kalacak yeri ve parası olmayanlar hijyenik olmayan ortamlarda kalabiliyor. Buda yaranın iyice büyümesine, gangren gelişmesine ve hatta ayağın kesilmesine kadar gidebiliyor. O yüzden öncelik hep kendilerinde olsun istiyorlar ve tedavi sirasinı gözetmiyorlar. İkna etmekte çok zorlanıyorum. Okuma yazma bilmeyenlere ilacın kullanımını anlayacağı dilde anlatmak ta zorlaniyorum. Zira iyi anlasinlar diye defalarca tekrarlasam da "nasıl yapacaktın" diye sorduğumda yanlış cevap verince beni hiç dinlemediğini düşünüp sinirlenebiliyorum. Ama yine de yansitmamaya çalışıyorum. Birçoğu haklarını bilmiyorlar ve tedavi önceliği ve yatak bulma konusunda diğer personeller tarafindan haksızlı̆̆a uğrayabiliyorlar. Bunu gözlemlediğim zamanlarda da öğrenci olduğum için müdahale edemiyorum ve çok üzülüyorum. Ayrıca yabancılarla dil problemi de yaşıyorum. Tercüman eşliğinde iletişim kurmaya çalışlyorum. Bu da çok zor oluyor.

G7: Hastaların çoğu kanserli oldukları için çok hassaslar. Bizim mimiklerimizden bile anlam çıarlyorlar. Çok fazla, bazen de soru soruyorlar.(5 dakikada bir saat kaç, bugün haberleri dinledin mi, falan dizinin sonu ne oldu, sen evli misin veya arkadaşın var mı”vb. Öğrenci olduğum için beni tecrübesiz görüyorlar. Tedavilerini 994 
yaptırmak istemiyorlar. Hastalıklarının gidişatı ile ilgili onlardan bir şeyler saklanıyormuş gibi düşünüp beni gördükleri yerde "dr veya hemşire vizitte şöyle dediler (tıbbi terim olarak) bu ne demek, ben kötü müyüm, neden aileme haber vermiyorsunuz" gibi sorular karşısında bazen bunallyorum ve ne cevap vereceğimi şaşırıyorum. Bazende açıklama yapsam bile bir süre sonra aynı sorularla karşılaşınca beni hiç dinlemediklerini düşünüyorum. Maske takmak ve ellerini çok sık yıkamak onlara zor geliyor. Kontrollerde hatırlatınca da ters cevaplar verebiliyorlar, "sana ne, sen kimsin, anladik git buradan, beni mi takip ediyorsun, sende yettin artik" gibi. Ama hemşire ablalara veya doktorlara böyle cevaplar veremiyorlar.

G8: Hastalar klinikle, hastallklarlyla ve benim görevlerimle ilgisi olmayan gereksiz sorular soruyorlar.Çoğunlukla cevap vermiyorum veya geçiştiriyorum. Bu seferde ben duyacağım şekilde "suratsız hemşire" kimliğini yapıştırıyorlar ve iftiralar bularak hemşire ablalara şikayet ediyorlar. Bu durumda o hastayla iletişimimiz tamamen kopuyor. Ayrıca EKG çekerken kadın hastalar erkek arkadaşları istemiyorlar hatta onlara tedavilerini de yaptırmıyorlar. Dr konusunda cinsiyet önemli değil ama biz olunca ayrıma gidiyorlar bu da problem yaratıyor. Bazı hastalarda her şeyi çok bildiklerini düşünüp uygulanan tedaviyi beğenmiyorlar, ayrıntıl sorular soruyorlar, başka yerlerde de tedavi olmuşlarsa orası ile klyaslamalar yapıp bizi eleştiriyorlar. Bu durumda o hastayla çok fazla iletişime girmeden işimi yapıp çıkıyorum.

G9: “Öğrencilere karşı ön yargılı olduklarından uygulamaları yaptırmak istemiyorlar. Hoşgörülü olduğumda sorun büyümüyor, büyürse de hemşire ablayı çağırıyorum. Geri çekiliyorum. Bunun dışında pek sorun yaşamıyorum."

G11: Ben en çok hastanın tedaviyi reddetmesi, yaptı̆̆ım işleri sorgulaması, gereksiz isteklerde bulunması gibi iletişim sorunları yaşıyorum. Dil problemi yaşadığım hastalarım da oluyor.

G12: Çalıştı̆̆ım poliklinikte hemen hergün muayene sırası ve hastaların birbirlerinin sıralarını gaspetmesi sonucu kavga çıklyor. 65 yaş üzeri öncelikli olunca durumu daha acil olan hastalar buna itiraz ediyor. Poliklinikte çoğu kez bu kargaşayla tek başıma başa çıkmak zorunda kalıyorum. Hastalar anlatmaya çalıştığım her şeyi hakaret etmiş gibi görüyor ve sürekli çatışıyoruz. İçeri girince beni yapmadiğım söylemediğim şeylerle iftira atıcı şekilde dr a şikayet etmeye çalışıyorlar. Sistemden kaynaklanan sorunların suçlusu benmişim gibi bazen tehditkar konuşmalar dahi yapabiliyorlar, korkuyorum ve hastaneden çıkı eve giderken takip ediliyorum hissine bile kapıldığım oluyor. Muayene esnasında ise birden sakinleşip dr a karşı gayet saygılı davranıyorlar.

Görüşmelerden elde edilen bulgular, hemşire adaylarının yaşanabilecek tüm problemlerin hemen hepsini staj süresince yaşadıklarını göstermektedir Çalışma deneyimlerinin az olması ve hastaların ön yargılı davranışları yaşadıkları iletişim sorunlarını anlamlandırmalarını güçleştiriyor. Fakat yine de, sorunlarla 11. sınıfa göre daha kolay baş ettiklerini, hastaları tanımak ve anlamakta daha az zorlandıkları ve hasta bakımı uygulamalarındaki becerilerini de arttırdıkları için kendilerine daha çok güvendiklerini söylemişlerdir.

Hemşire adayları, kendilerini iyi tanıyıp, becerilerini fark edebildiklerinde kendilerine güvenleri artacak, kendilerine güvenleri arttığında ise gözlem ve karar verme becerileri gelişecektir.. Ayrıca, hemşire adayı bir adölesan olmasına rağmen yetişkin sorumluluklarını üstlenebilmekte, kurduğu çeşitli iletişimlerle benliği zenginleşmekte, ufku genişlemekte ve benliğinde yaşıtlarından daha hızlı değişimin sancısını yaşayabilmektedir. Bir süre sonra aynı yaşantıları paylaşmamış olan akranlarından ayrışma ve yalnızlık duygusu hissedebilmektedir. (Terakye,1994:21). Kliniklerde karşılaşılan tedaviyi ve etkili hemşirelik bakımını olumsuz etkileyen, hemşire adaylarının, fizyolojik ve psikolojik anlamda güçlük yaşamasına neden olan zor veya problemli hasta davranışlarına müdahale ederken, dikkat edilmesi gereken noktalar vardır. Bunlardan ilki hastayı hastalıktan ibaret nesne gibi değil, yardım gereksinimleri olan yetişkin bir birey olarak kabul etmektir. Hastayı aktif şekilde dinlemek, hastanın sözlü ve sözsüz davranışları ile ifade etmek istediklerinin ne olduğuna odaklanmak gerekmektedir. Bunun için hasta ile iletişimde iletişim tekniklerinden faydalanarak kendini ifade etmesine olanak sağlanmalıdır. (Göral,2011:9).

Görüşmelerde hemşire adaylarının Türkçe bilmeyen hastalara bakım verirken zorlandıkları da belirlenmiştir. Okulda aldıkları dil eğitiminin yetersiz olması, yabancı uyruklu hasta bakımına yönelik eğitim almamaları, dış göç ile Türkiye'ye gelen yabancı uyruklu hastaların Türkçe bilmemeleri, hastanede tercüman bulunmaması veya yetersiz olması hemşirelik bakımını olumsuz etkilememektedir. Bu nedenle kültürlerarası hemşirelik kavramının 
hemşirelik müfredatına eklenmesine yönelik gerekli düzenlemelerin yapılması, mülteci olarak ülkeye alınan bireylere Türkçe eğitim verilmesi, yabancı uyruklu hastaların yoğun olarak bulunduğu hastanelerde tercüman bulundurulması ve sayılarının yeterli düzeye çıkarılması gerekliliği ortaya çıkmaktadır (Polat ve Akcan, 2016:13).

\section{Hemşire adaylarının, kliniklerde hastalarla yaşadıkları iletişim sorunları karşısında nasıl davrandıkları}

Hastanelerde hemşire adaylarının sorun olarak gördükleri hasta davranışlarından biri "ağlama"dır... Yetişkin insanlar ağlama davranışını kontrol etmeyi öğrenmişlerdir, bu nedenle ağlama, kontrolü becerememenin, zayıflığın, yetersizliğin göstergesi olarak değerlendirilebilir. Ağlama bir tür iletişim biçimidir. Üzüntüyü, çaresizliği acı çekmeyi, engelleme ve öfkeyi yardım isteğini ağlama yolu ile ifade edebiliriz. Ağlama, bir duygu birikiminin göstergesidir. Bazen, ağlamayı başlatan son olay sadece bardağı taşıran son damladır (Terakye,1994:74).

Hemşire adayı ağlamasını durdurmaya çalışmaz, aksine ağlamaya izin verici davranır. Kişinin mahremiyetini gözeterek yalnız kalmasını sağlama gibi önlemler alabilir. Gerekiyorsa bir mendil uzatabilir. Sessiz kalarak veya omzuna hafif dokunarak ağlamasını ve gözyaşlarını kabul ettiğini gösterebilir. Hastayla konuşmak için ağlamasının bitmesi beklenmelidir. Ağladığını gördüğü bir hastaya, "ağlamayın" demeden veya "içinizden ağlamak geliyorsa ağlayın" da demeden çoğu sözsüz olan kabullenici davranışlar ortaya koyabilir (Özcan, 2006:166).

Sorun olarak görülen bir diğer davranış "tedaviyi reddetme"dir. Hastalar bazen bağımlılıklarını, yetmezlikleri nedeni ile kısıtlanmaları kabullenemezler.Servisin düzeni, çalışma planı hastanın hizmete katılan değil, hizmeti alan kişi olarak görülmesini ve olabildiğince odasında kalmasını gerektiriyor ise etkin bir yaşamdan edilgin yaşama geçişi alışkanlıklarının değişimini kabullenemeyen hastalar kendilerini kısıtlanmış, engellenmiş, yetersiz dolayısı ile depresif hissedebilir, bu duyguları sonucunda akıl almaz şekilde "tedaviyi, işbirliğini" reddedebilir, kendine zarar verebilir (Terakye, 1994:77).

Hemşire adayları hastanın kabul etmediği ve katılmadığı hiçbir uygulamayı hastaya rağmen yapamazlar. Tedavide ve bakımda hastanın işbirliği yapması ve kendisiyle ilgili tüm kararlara katılması sağlanmalıdır. Bunun için yetişkin hastalara beklenen davranışları, olumlu önerilerle yaklaşarak uygun olduğunu vurgulamak gerekir. Ayrıca, "yapmaması" gerekenler yerine "yapabileceklerini”" vurgulamak, kişilerin söyleneni dinleme olasılığını arttırır (Özcan, 2006:169).

Hastanın bilgi gereksinimi ve "dil sorunu"da iletişimde önemli yer tutar. Her hasta durumunu, hekimlerin kendileri hakkında ne düşündüklerini, hastalığının ne olduğu, tedavi olasılığı vb. pek çok konuda bilgilenmeye gereksinme duyar. Bilgilendirilmek aynı zamanda hasta haklarından biridir. Yeterince bilgilendirilmeyen hastaların tedirginliği artmaktadır. Bilgilendirme de kullanılan dilin anlaşılır olması gerekir. Özellikle hasta bakımı sırasında hastaların yanında; tıbbi terimlerle konuşmak, hastalığı konusunda yeterli açıklama yapmamak, soru sormasına olanak vermemek gibi yaklaşımlardan hastalar olumsuz yönde etkilenmektedirler. Yanlış anlamalara kendince yorumlar yaparak endişe ve korkularını artırmaya neden olmaktadır. Bu da hem hastaya hem de hemşire adayına ek bir sıkıntı yüklenmesi demektir (Özcan, 2006:186).

"Sürekli gereksiz isteklerde bulunan hasta"ların en önemli özelliği güvenlik gereksinimlerinin önceden belirlenmeyip yeterince karşılanmamış olmasıdır. Hasta korku ve yalnızlık içindedir. Her an yanında birilerinin olmasını ve onunla sürekli konuşmayı ister. Bunun için en yakınında gördüğü hemşire adayını sürekli meşgul eder, gereksiz isteklerle yanına çağırır, çoğunlukla bağırıp zorla gelmesini sağlar, yanında uzun süre tutmak için elinden geleni yapar. Hastanın bu davranışları karşısında altında yatan karşılanmamış gereksinimleri anlaşılmadığı sürece sürtüşmeler yaşanır. (Özcan, 2006:182).

Hemşire adayları kimi zaman hastaya yakınlık gösterdiklerinde bu yakınlığın hasta tarafından yanlış anlaşılabileceğinden ve yorumlanabileceğinden endişe etmekte, bu yüzden uzak durduklarını belirtmektedirler. Hasta davranışını yönetmede kendilerini henüz yeterli hissetmemelerinin bunda büyük rolü vardır. Hasta davranışını yönetmek, belli bilgi birikimi ve profesyonel beceriler gerektirmektedir. Ancak, şunu hiç unutmamak 996 
gerekir; hasta hemşire adayına ne gözle bakarsa baksın, hatta "cinsel obje” olarak da görse, önemli olan hemşire adayının kendisini ne gözle ve nerede gördüğüdür. Eğer kendisini asla böyle görmüyor ve sorunları çözmesi için hastalara yardım eden bireyler olarak görüyorsa kimse onu başka bir gözle göremez. Böylece hasta; cinsel anlamda gönderdiği mesajın, gönderildiği anlamda algılanmadığını anlayacak ve davranışını kontrol altına alabilecektir. (Terakye,1994:78).

Hemşire adayları yaşadıkları iletişim sorunları karşısında nasıl davrandıklarını çeşitli örneklerle açıklamışlardır. Buna göre iletişim engelini ortadan kaldırmada empati yapmanın rolü ve etkisini, $\boldsymbol{G} 1$ : "Yaşadığım sorunlar yüzünden şimdiye kadar hastalarla hiç çatışmaya girmedim. Karşımdakinin bir insan olduğunun farkındayım ve empati yaparak onu anlamaya dinlemeye çalışıyorum. Ĕ̆ger başarılı olamazsam odayı terk edip hemşire ablalara söylemeyi tercih ediyorum”. G2: “Hastaların duygu ve düşüncelerini empati yaparak tahmin etmeye çalışıyorum. Fakat bazen bunu başaramıyorum. Biz erkek hemşirelere karşı bu kadar ön yargılı olmaları geleceğim için endişe duymama sebep oluyor. Önce nazik bir dille konuşmayı ve her şeyi ayrıntısıyla izah etmeyi deniyorum. Çoğu zaman başarll olsam da, faydası olmazsa hemşirelere durumu bildiriyorum" şeklinde belirtmişlerdir.

Hastalara karşı hoşgörülü olma nın önemini, G5: “Genellikle hoşgörü gösteriyorum. Ilımlı davranıyorum. Bazı personeller çok agressif davranıyorlar. Bana göre çok yanlıs yapıyorlar, çünkü böyle zamanlarda olay iyice büyüyor. Çatışmalar çoğalıyor”. G7: “Davranışlarını çoğu kez hoşgörüyle karşıllyorum. Onlara saygi duyuyorum. Ziyaretçi fazla kabul edilmeyen bir klinik olduğundan kendilerini çok yalnız hissediyorlar. Onlara daha çok zaman ayırmaya ve enfeksiyon bulaştırmama kaidelerine de uyarak konuşmaya çalışıyorum. Çalıştı̆̆ım kliniğin hemşireleri çok çalışkan vre hastalarla genellikle iyi bir iletişimleri var. Ama ara sıra çok emrivaki konuştuklarını ve hastaları küçümseyici davrandıklarını da görüyorum. Olumlu yanlarını örnek alıyorum”. G9: “Hoşgörülü olmaya çalışlyorum. Empati kuruyorum. İ̧̧e yaramazsa da hemşirelere bildiriyorum.

Hastalara, iyi davranma ve güleryüzle yaklaşma konusunda, G8: Hastalara sert davranan hemşireler olabiliyor. Ben bunu yanlış buluyorum ilerde benim mesleğe atandığımda aynı şekilde davranırmııım acaba diye düşünüyorum ama daha sabırlı güleryüzlü olabileceğime inanıyorum. G11: "Şu iki yıllık çalışmamda empati kurma ve sınırı iyi ayarlamaktan başka çözüm bulabilmiş değilim.Çünkü hastalar fazla güleryüz gösterip iyi davranınca hemen bunu kullanmaya çalışıyor ve bize farklı gözle bakıyor. Birde yaptı̆̆ım uygulamaları hatasız yapmaya çalışıyorum ki bize karşı ön yargıları değişsin”. şeklinde ifade etmişlerdir.

Hastalarla olumlu ve uygun ve sakin bir dille konuşma,onları dinleme, zaman ayırma, açıklama yapma, konusunda, G3: “Karşılıklı konuşma yollarını birkaç kez denediysem de öğrencilere karşı ön yargılı olduklarından çok başarılı olamadım. Çözümü çoğunlukla hemşire ablalara söylemekte buldum. Bazen onlarında çatışmaların altından kalkamayıp güvenlik görevlilerini çağırdıkları oluyor. Hastalar hep kendilerini haklı görüyorlar ve bunu kanıtlamak içinde sürekli bağırarak açıklama yapıyor. Ben böyle durumlarda kenarda kalmayı ve sakin olmayı tercih ediyorum”. G4: "Çoğu zaman diğer să̆lı personellerinin tutum ve davranışlarını gözlemliyorum. Gözlemlediğim kadarlyla onların hastalara olan tutumunu biraz sert buluyorum, bana göre bu doğru bir davranıs değil. Ama hastalarla gayet güzel bir dil ile konuşan ve onları dinleyerek sorunları çözen personellerde var elbette. Ben genellikle onlarl örnek altyorum. Hastalara daha ılıml yaklaşmaya çalışlyorum”. G6 ve G10: "Empati yapıyorum. Olayı büyütmeden çözmeye çalışlyorum. Ayrıca çalıştı̆̆ım kliniğin hemşiresi ve dr u çok sabırlılar. Problemleri güzel çözümlüyorlar. Hastanın anlayacağı dilde her uygulamayı çok güzel izah ediyorlar. Ayrica birde evde yapacaklarl pansumanlarl tarif eden yazılı bir doküman da veriyorlar. Hastalar genellikle memnun kalıyor. Sorun çok olsa da çabuk çözülüyor. Ben de daha çok onları örnek alıyorum. Uzun tedavilerden sonuç alamayıp artık tedaviyi iyice bırakan hastalar da var. O hastaları da motive etmek için uzun zaman ayırıp konuşuyorlar” demişlerdir.

Hastalarla yaşanan çatışmalara kendi üslubunca farklı çözümler bulmaya çalışmak seçeneğine ise, G12: “Gözlemlediğim kadarıyla tüm personelin hastaya davranış şekilleri farkl. Ben aralarından olumlu davranışları seçmeye çalışsam da kendim gibi olmayı ve kendi irademle sorunları çözmeye çalışlyorum. Çalıştı̆̆ım poliklinikte başka hemşire olmadığından söyleyecek kimse de yok. Dr. zaten benim hastayla olan iletişimimle ilgilenmiyor. Dışarıda çok hasta baskısı ve sıra kavgası olduğundan hastayı içeri alır almaz hemen 
kapıyı kilitliyorum ekranda yazan hasta dışında aradan almamaya çalışıorum. Hakaretleri de duymamazlıktan geliyorum ve genellikle cevap vermiyorum" şeklinde ifade etmiştir.

Hemşire adayları sorunlar karşısında çoğunlukla empatik davranış gösterdiklerini söylemişlerdir. Empati başkasının duygu-durumunu kavrama yeteneğidir. Günümüzde "empati” denildiğinde akla Carl Rogers ve onun konuya ilişkin çalışmaları ve büyük çoğunluğun bu çalışmalara göre üzerinde anlaştığı tanım gelir. Rogers, (1970) e göre, empati, bir kişinin kendisini karşısındaki kişinin yerine koyarak olaylara onun bakış açısıyla bakması, o kişinin duygu ve düşüncelerini doğru olarak anlaması, hissetmesi ve bu durumu ona iletmesi sürecidir (Akt. Dökmen, 2003:135).

Travelbee insanları yardım etmeye yönelten bir duygu olarak' "Sempati"yi tanımlar ve yeterli kalitede sempati olmazsa gerçek anlamda hasta-hemşire ilişkisinin kurulamayacağını belirtir. Travelbee, (1971) e göre hemşirelik; iki insan arasındaki kişilerarası süreçtir Hemşirenin hedefi; bireyin hastalık durumu ile baş etmesin de, yaşantıdan bir anlam çıkarmasında, yaşantıların her biri ile gelişmesinde bireye yardım etmektir. ve bu hedeflere ulaşmak için, ilk karşılaşma, kimliklerin ortaya konması, empati, sempati aşamalarından geçilir. Sempati acıma duygusu ile karıştırılabilir. Acıma insanca bir duygudur ama "ne zavallı insan" duygusunu yaşamak karşıdaki hasta bireyi anlamaya değerlendirmeye yaramadığından ve onu aşağılarda, kendini hastadan daha üstün görmekten başka bir işe yaramaz. Hemşirelerin meşgul oldukları için sempatiye ve ilgiye zaman ayıramadıkları savunusu getirebilir. "Klinikteki hemşirenin görevi hasta ile ilgilenmek değilse ne ile ilgilenmektir? Hemşirelerin kurdukları ilişkinin niteliği, hemşirelik yaparken neyi ön planda tuttukları ile bağlantilıdır (Terakye, 1994:112).

Hemşire adayları da, hastalarla iletişim sorunu yaşandığında, çoğunlukla sorunu hemşirelere ilettiklerini ve onların, olumlu ve etkili bulduğu davranış modelini benimseyerek hareket ettiklerini belirtmişlerdir.

\section{Öğrencilerin, staj yaptıkları kliniklerde diğer sağık çalışanları ve hasta yakınlarıyla yaşadıkları sorunlar}

Hemşire adayları staj yaptıkları kliniklerde fizik ortam, öğretim elemanları, klinik hemşireleri ve sağlık ekibinin diğer üyeleri gibi birçok faktörden etkilenmektedir. Bu nedenle uygulama yapılan kliniklerde görevli olan hemşire ve diğer sağlık ekibi üyelerinin bilinçli, deneyimli ve mesleki yönden donanımlı, olumlu rol modeli olması uygulama hedeflerine ulaşılması açısından önemlidir (Turan,Tan ve Dayapoğlu, 2017:171).

Hemşire adayları, yetkin bir hemşire kimliği kazanmak için bu ortamı optimum düzeyde kullanmak durumundadır. Ancak hastaneler, birçok sağlık profesyoneli, hasta, hasta yakınları, diğer yardımcı personelin bulunduğu, dış dünyadan farklı ortamlardır. Hemşire adaylarının, bu ortama uyum sağlaması, hastaların haklarını ihlal etmeden klinik beceri kazanması gerekmektedir. Ancak, klinik eğitim sürecinde hemşire adaylarına yönelik etik ihlaller olabilmektedir (Aydoğan, 2016:123).

Hasta yakınları hastası için endişelenen, onun bir an önce sağlığına kavuşmasını dileyen, acil durumlarda panikleyen, diğer zamanlardan farklı olarak, daha kırılgan ve stresli bireylerdir. Daha önceden hastane deneyimleri olabileceği gibi, ilk defa sağlık kuruluşuna gelmiş de olabilirler. Yeni bulunduğu ortamda korku, endişe, heyecan yaşayabilirler. Daha önceden gördüğü bazı olumsuz olaylar önyargılı olmalarına neden olabilir. Hasta yakınının özelliklerine göre iletişim kurmak çok önemlidir. Her birinin tepkileri farklı olabilir. İletişim kurmak için bu tepkileri bilmek gerekir (Sağl1kta İletişim modülü, 2015:18).

Hemşire adaylarının, sağlık çalışanları ve hasta yakınlarıyla yaşadıkları sorunları belirlemek için kendilerine sorulan sorulara verdikleri yanıtlar şöyledir.

G1: Sağllk çalışanlarıyla sorun yaşamıyorum. Sadece kendi üstüme düşen işleri yapıyorum. Sağlık çallşanları benden ekstra bir iş beklemiyor. Fakat bazen kendi aralarında hasta paylaşımı konusunda sorun yaşanıyor. Hasta yakınlarınin ise bizden ekstra şeyler talep etmesi (tansiyonların, şekerlerini ölçtürmek, ağrl kesici istemek $v b$.)sikıntı yaratabiliyor. Karşılayabildiğimiz ölçüde isteklerini yapıyor veya hemşirelere iletiyorum ama karşılayamadığım zaman arkamdan dedikodu yapıyorlar. Hemen tavırları değişiyor. Birde ziyaret saatlerinden sonra odayı boşaltmamak için direnenler oluyor. Onlarla da çoğunlukla kavga çıkmadan konuşup hallediyorum. 998 
G2: Bazı hemşireler kendi yapmaları gereken işleri bize yaptırmaya çalışlyorlar. Hasta bakıcıların hatta temizlik personellerinin bile yapmaları gereken işleri bize yaptırlyorlar. Benim erkek olmam da ekstra işlere maruz kalmamda etkili oluyor. "Sen erkeksin falan kişiyi çağırmayayım şimdi hadi falan hastayı sen taşı endoskopiye, çayımız bitmiş aşă̆ı kantine inip al, hastanın sahipleri malzeme getirmiş aşağ inip getir” gibi ayak işleriyle uğraştırıyorlar. Sıkıntı yaşamamak için çoğunlukla sesimi çıkarmıyorum. Öğretmenlerimin kendileriyle konuşmaları da fayda sağlamıyor. Şikayet etmiş konumuna düşüyorum. Onlar yokken daha çok yükleniyorlar. Zaten az zaman kaldı mezuniyete idare ediyorum. Hasta yakınları da hastaya işlem uygulamaya gittiğimde ĕger beni ilk defa görüyorsa, "sen yapamazsın acıtırsın” gibi ön yargll davranıyorlar. Güven vermeye çalışarak işimi yapıyorum. Çok ısrar ederlerse de hemşirelere haber veriyorum.

G3: Hastay sedye yada sandalyeyle bir yerlere götürülmesi gibi işlemleri genellikle bize yaptırlyorlar. Oysa hastanın yanında sadece biz olmamalıyı. Bir hemşirede bulunması gerekir. Ama size güveniyoruz falan diyip tek başımıza bırakıyorlar. Taşımakta güçlük çekiyoruz personelden de kimse gelmiyor. Bel ă̆rıları yaşıyorum bu yüzden. Hasta yakınları da çok sinirliler. Argolu küfürlü konuşmalar çok oluyor. Sorunlarını ve isteklerini etkili bir biçimde ifade edemiyorlar. Direk ön yargı geliştirip kavga ediyorlar. Her zaman güleryüzlü olmamızı ve başka hasta yokmuş gibi hep kendi hastalarlyla ilgilenmemizi istiyorlar. Bir yere giderken veya refakatçi değişecekse haber verme zahmetinde bulunmuyorlar. Ben genellikle sakin ve anlayışl olmaya çalışlyorum.

G4: Muayeneye gelen çocukların anne babalarıla bazen yaşıyorum. Bazıları çocuklarına benim dokunmamı istemiyorlar. Ön yargllart var. Ë̆itici konuşmaları ben yapınca hiç önemsemiyorlar dinlemiyorlar. Doktora soruyorlar. Doktorlar da bazen anlatıyor ama çoğunlukla hastalar yetişmez diye zaman ayırmıyorlar. Yabancı uyruklu hasta yakınlarıyla da dil problemi yaşıyorum. Sağlık personeliyle sorun yaşamıyorum.

G5: Sağlık çalı̧̧anları bazen görevimiz olmayan isteklerde bulunuyorlar ama bunu dostluk rica şeklinde söyleyince yapıyorum. Sorun çıkmıyor. Servis hasta sayısına göre çok yetersiz. Hastalar bazen yatak boşalıncaya kadar sedyede kalabiliyor. Yanlarında çok fazla yakınları oluyor. Hepsi kaygılı ve meraklı aşırı derecede gerekli gereksiz soru soruyorlar. Tedavi yaparken daracık yerlerde zorlaniyorum. Hasta yakınlarını uygun bir dille çıkarmaya çalışıyorum fakat benimle hemen tartışmaya başlıyorlar. Vizit saatlerinde bile bazen güvenlik çağırarak boşalttırıyoruz odaları.

G6 ve G10: Bazen görevim olmayan iş beklentisi olduğunda veya yanlış anlaşıldı̆̆ımda kibarca söyleyerek reddediyorum ve olayı büyütmeden bitiriyorum. Hasta yakılarl çoğunlukla anlayışsız, bize tedavi uygulatmak istemiyorlar veya bağırıp çağırabiliyorlar. Her işlemi doktor yapsın istiyorlar. Bazen hemşireye bile yaptırmak istemiyorlar. Sabırla anlayışla hoşgörü ile işimizi yapmaya çalışıyoruz. Ayrıca bazı hasta yakınları da sürekli kendi hastalarını bize şikayet ediyorlar. "Söylenilenleri evde yapmıyor yaptırmıyor, benimle kavga ediyor konuşun siz ikna edin ben baş edemiyorum"gibi sözlerle bizden yardım talep ediyor. Poliklinikte tüm personel elinden gelen her şeyi yapıyor.

G7: Bazen servisin temizlik işleri vizit saatine yetişmediğinde bizden temizlik personeline yardım etmemiz isteniyor. Bazen de ayak işleri yaptırıorlar. Şunu götür bunu getir, kendimi posta gibi hissediyorum. Servis sakinken de gözlerinden uzak olalım istiyorlar. Ayak bağı oluyormuşuz. Hasta yakınlarının da bazıları çok bencil ve merakl. Sadece kendi hastalartyla ilgilenelim istiyorlar. Başka hastalara hangi tedavileri uyguluyoruz merak edip takip ediyorlar. Ona şunu yaptın benim hastama neden yapmadın gibi hesaplar sorabiliyorlar. Sağlık personeline çok güvenleri yok bence. Hep anlayışlı ve sakin davranan biz oluyoruz. Yoksa kavga çıkacak biliyoruz.

G8: Bize sorumlu olmadığımız işleri yüklüyorlar bazen yemek saatimizi bile gasp etmeye çalışlyorlar. Hele bir hemşire var ki zulmediyor diyebilirim. Bir kez karşı çıkmaya kalktım, hemen beni sorumluya abartarak şikayet etti. Servisten atılma tehlikesi bile geçirdim. "Siz buradan para allyorsunuz, yapmak zorundasinız buraya oturmaya mi geldiniz gibi hakaret edebiliyorlar. Her zaman yaşanmasa da olduğu zaman çok etkileniyorum. Ağllyorum, öğretmenimi arıyorum ama bir süre sonra unutuluyor. Hasta yakınları da sanki hastalarlyla ilgilenmeye değil de oğullarına veya yakınlarına kız bulmaya gelmiş gibiler. Sürekli bizlere takllyorlar. Merak içindeler her şeyimizi ögrenmeye çalışıyorlar. Bazen duymamazlıktan geliyorum, kısa cevaplarla geçiştiriyorum dikkatini, hastasının üzerine çekmeye çalışıyorum. 
G9: Sağllk personeliyle neredeyse hiç sorun yaşamıyorum. Bize karşı çok anlaylşll ve koruyucu bir tavır sergiliyorlar. Kliniğe Hasta yakınları çok fazla giremiyor. Enfeksiyon riskinden dolayı. Bazen zorla girmeye çallşıllarsa ufak tefek problemler yaşaniyor.

G11: Hemşireler sanki kendileri hiç ögrenci olmamış gibi bizden yapabileceklerimizin çok üstünde iş bekliyorlar. Kendileri sadece odalarına çekilip tedavilerde bizi yalnız birakiyorlar. Bir defasında "hastanın tansiyonu çok değişkenlik gösteriyor emin olamadım birde siz ölçermisiniz" dedim. "Sen çok güzel ölçüyorsun, yanllş değildir merak etme, kaydet gitsin" diye cevap verdi. Ayrıca servisin sekreterya işlerini de bize yaptırlyorlar. Tedavi yoksa sürekli dosya doldur, defter yaz, tedavi masasinı temizle, malzemeleri say vb. her işi bize yaptırlyorlar. Bazen bize nasll bu kadar güvenebiliyorlar diye de şaşırtyorum. Ben her ne işolursa olsun asla hastanın zarar görmesini istemediğimden, titizlikle yapıyorum. Çatışmaya girmiyorum. Ben durup dururken saldirganlaşan sinirlenen bir hasta yaknnyla karşllaşmadım. Hastalarına yeteri kadar zaman ve gerekli bakım uygulanmadığında hesap sorabiliyorlar. Anlayışlı davranıp güven verirsek çatışma olmuyor.

G12: Görevim olmayan işleri yapmamı istediklerinde, "hayır yapmayacağım" dediğim zaman hemen tavır alıp şikayet ediyorlar. Bazen de psikolojik bask uyguluyorlar. Hiç yokmuşuz gibi davraniyorlar. Poliklinikte hastalar bitti öğlen tatili yaklaştt. Dr bana "git şu kantinden bana su alda getir" dedi. Ben de "yemeğe gidicem suyu alsam bile geri dönüp veremem" dedim. Aynı dr la poliklinik sirası bitinceye kadar 1 hafta daha çalışmak zorunda kaldım ve ben yokmuşum gibi davrandl. Bir kez "günaydı" dedim ona bile cevap vermedi. Bir doktora da bunu hiç yakış̧ıramadım.

Hemşirelik eğitiminde teorik bilginin beceriye dönüştürülmesinde ve hemşire adaylarının mesleki becerilerinin geliştirilmesinde klinik uygulamanın önemi tartışılamaz. Görüşmelerde hemşire adayları; diğer sağlık personeliyle iş yüklerini çoğaltma, alakasız işler yaptırma, kendilerini ekibin bir paçasıymış gibi görmeme, itiraz ettiklerinde çeşitli yaptırımlar uygulama, anlayışsız ve bazen de acımasız davranmalarına maruz kalma gibi sorunlar yaşadıklarını belirtmişlerdir. Hasta yakınlarıyla da sorunlar yaşadıklarını ve bazen kendilerini hizmetçileri gibi gördüklerini bencilce hareket ettiklerini, anlayışlı davranmadıkları takdirde her an kavgaya meyilli olduklarını söylemişlerdir.

Hasta yakınları ile iletişim kurarken, herkesin hastalığı ve hastalık yaşantısının farklı olduğu unutulmamalı, umudu azaltan başka öykülerden söz edilmemelidir. Bu süreçte, hasta yakınını dinlemek ve onun yaşadıklarını paylaşmak, en iyi duygusal destek sayılabilir. Hastanın ihtiyaçlarının öne çıktığı tedavi sürecinde, hasta yakını kendi sıkıntı ve ihtiyaçlarını ihmal edebilir. Uyku, yemek, stres gibi problemler yaşayabilir ve uzman desteği gerekebilir. Herkes böyle zor bir deneyimde; sevildiğini, değerli olduğunu, yalnız olmadığını hissetmek ister ve çevresinin desteğine ihtiyaç duyar (Sağllkta İletişim modülü, 2015:19).

\section{Hemşire adaylarının, yaşadıkları iletişim problemlerinin çözümüne yönelik görüşleri}

İletişim ve iletişim becerilerinin, hemşirelik eğitiminde ve uygulamasında yaşamsal bir rol oynadığı ve sağlık bakımının nitelik ve niceliğinde engelleyici faktörlerin başında etkisiz iletişimin geldiği kabul edilmektedir (Özcan, 2006).

Sağlık hizmetlerinde, hasta- personel, hasta yakını- personel, personel- personel arasındaki ilişkilerde bir uyum ve bütünlük olması hizmetin kalitesi açısından çok önemlidir. Eğitim hastanelerinde öğrenci hemşirelerin de sağlık ekibinin bir üyesi olarak görülmesi ve iletişim de yaşanan sorunlara karşı onlarında görüş ve önerilerine önem verilmesi gerekir. Bu amaçla öğrencilere iletilen sorulara verdikleri yanıtlar şöyledir.

G1: Önerilerim; 1- Hastanelerde doktora saygı gösterildiği kadar hemşireye de saygı gösterilmesi gerektiği hakkında seminerler düzenlemek. 2- Hastalarla iyi bir iletiş̧im için güven ortamı sağlamak ve hasta yakinlarının aklina takilan tüm sorulara cevap vermek. 3- Her servisin odasina hastane kuralların asmak ve bunların okunmasın sağlamak. 4- Okulda aldı̆̆ımı meslek derslerinde teorikten çok uygulamaya yönelik eğitim olması gerekir. Dersleri hastane ortamındaymış gibi işlememiz ve gereksiz meslek derslerinde gereksiz bilgiler yerine hastanede karşılaştı̆ı̆mı sorunlara karşı nasıl davranacağımız öğretilirse sorunlar azalmış olur. 
G2: Önerilerim; 1 - Herkesin karşılıklı olarak birbirleriyle empati kurması ve birbirlerini her konuda anlayışla karşılaması gerekiyor. 2- Hastaların ve hasta yakınlarının, sağlık çalışanlarına karşı önyargılarını kırmaları gerekir (özellikle erkek hemşirelerinde artık kabullenilmesi). 3- Sağlık çalışanlarının da hastalara karşı daha sevecen, samimi, ilgili olması gerekir. 4- Hasta ve sağlık çalışanları arasındaki iletişimin nasıl olmasına dair, her iki tarafa da ĕgitim vermek gerekir. Çeşitli konferanslar, anketler düzenlenmelidir. 5- Bu tür sorunlarla karşılaştı̆̆ımızda her iki tarafında nerelere başvuracă̆ ve ne yapacă̆ı konusunda ĕ̆itim verilmelidir.

G3: Önerilerim; 1- Hastalar, sağllk personelini hizmetçi gibi görmemeli. 2- Hasta ve hasta yakınlarına da davranış eğitimi verilmeli. 3- İletişim dersleri uygulamalı olmalı. 4-Çok sinirli hasta ve sağlık personeline öfke kontrolüne yönelik ĕgitim verilmeli. 5- Hastalarda, să̆lık personeline karşı ön yargllarl yıkmaya yönelik çalışmalar yapılmalı.

G4: Önerim; hastanede yatan hastanın psikolojisini çok iyi bilmeli ve bunu göz önünde bulundurarak empati yapmall.

G5: Önerilerim; 1- Her sağlık personeli öncelikle iletişi sürecinde mutlaka empati kurmalıdır. 2- Sağlık personelinin hasta haklarına saygll ve belli kurallara mutlaka uymasl ve bunun bir sorumlu tarafindan sürekli denetlenmesi gerekir.

G6: Önerilerim; 1- Dil sorunu yaşadı̆̆ım hastada tercüman yardımı almalı. 2- Hasta yakını ile sorun yaşıyorsam, tedavi uygularken uygun bir dille dışarı çıkması sağlanmalı. 3-Sabırlı, açıklayıcı ve net olunmalı.

G7: Önerilerim; 1- Hemşireler ve hastalar birbirlerine karşı ön yargll olmamalı. 2- Karşılıklı empati yapılmalı. 3- Hasta ve yakınlarına karşı anlayışlı olmalı ve düşüncelerine saygı duyulmall. 4- İletişimle ilgili aldı̆̆ımı derslerde hiç görmediğimiz farklı sorunlar ortaya çıkıyor. Bunun için bu derslerin kapsamı genişletilmeli ve uygulamaya yönelik olmall.

G8: Önerilerim; 1- Öncelikle şunu söylemeliyim, sorunlar asla tek taraflı yaşanmiyor. Hastane ortamında herkes stresli. Hastane yönetimi, doktor, hemşire, hasta, hasta yakını, güvenlik, personel vb. hastanede bulunan herkesin yapması gerekenler ve uyması gereken kuralların açıkça yazılı olduğu raporlar oluşturulsun ve herkes bu raporu okusun anlasın, uyacağına dair imza atsın. 1- Hasta iletişimi ile ilgili çok sık hizmet içi eğitimler ve konferanslar verilsin.

G9: Önerilerim; 1- En çok görev biz hemşirelere düşüyor. Çünkü hastayla 7/24 biz iletişim kuruyoruz. Bizim daha hoşgörülü, empatik ve hastanın kararlarına saygılı davranışlar sergilememiz gerekir. 2- Aldığımız dersler çok yetersiz. Çok hayali kalıyor. Ezbere dayanıyor, bir süre sonra öğrenilenleri tamamen unutuyoruz. Illetişim derslerini her sene almalıyız. Tüm sorunları gerçekçi ve uygulamalı olarak, daha geniş kapsamda işlemeliyiz.

G10: Önerilerim; 1- Hastanın düşüncelerini ve kaygllarını yadırgamamalı ve yargılamamalıyı. 2- Hastaları daha dikkatli dinlemeliyiz ve empati kurarak anlamaya çalışmalıyız. 3- Hastalara karşı ön yargılı olmamalıyız. 4- Hastalara karşı saygılı davranmalı, onların haklarını korumalıyı.

G11: Önerilerim; 1- Să̆lık Hizmetlerinde Iletişim, Tıbbi Etik, Psikoloji, Ruh Să̆lı̆̆ ve Psikiyatri gibi derslerimiz var. Ancak teorik bilgiler sınav gününe kadar kalıcı, yaşanarak öğrenilen şeyler ise hiç unutulmuyor. Dersleri daha kapsaml ve uygulamalı işlemeli ve yaşadıklarımızdan, yaptığımı hatalardan ders alıp tekrarlamadan hastayla olan iletişimimizi her geçen gün olumlu yönde geliştirmeliyiz. 2- Öncelikle şunu unutmamalıyı. Hiç kimse mecbur kalmazsa hastaneye gelmez, klinikte yatmaz. Hastaların sağllkçılara ve özellikle de hemşirelerin şefkat ve ilgisine çok ihtiyacı var. Bizler, mütevazi, güleryüzlü, empatik, ve pozitif davranışlar sergilemeliyiz. 3-Doktorlarda hastayı oyalamamalı tedavilerine çözüm odakl yaklaşmaları gerekir. Hemşireler olmadan tedavi edemeyeceklerine inanmalart ve onlara daha saygılı davranmalarl gerekir.

G12: Öncelikle hasta psikolojisini düşünerek ve onların düşüncelerine öncelik vererek iletişim kurmalıyız. Çözüm de sadece hemşirelerden beklenmemeli herkes üzerine düşeni yerine getirmeli diye düşünüyorum. 
Görülmektedir ki öğrenciler yaşadıkları sorunların çözümünde ilk olarak empati kurmayı, eğitim süresince gördükleri derslerin; sorunları gerçekçi olarak yansıtması ve uygulamaya yönelik olmasını, hastaların; hemşireyi hizmetçi gibi görmemeleri ve doktora gösterdikleri saygıyı kendilerine de göstermesi gerektiği, doktorların da hemşirelere karşı daha saygılı davranmaları gerektiğini, karşılıklı ön yargıların tamamen ortadan kaldırılmasını ve karşılıklı-sağ lıklı iletişim tekniklerinin tüm taraflara hizmet içi eğitimler yoluyla çok sık verilmesi gerektiğini söylemişlerdir.

\section{Hemşire adaylarının yaşadıkları veya gözlemledikleri, onları en çok etkileyen unutamadıkları bir sorun}

$\mathrm{Bu}$ bölümde hemşire adaylarının anlattıkları yaşanmışlıklardan ve deneyimlerden seçilenler, en gerçek haliyle, örnek olay şeklinde verilmeye çalışılmıştır.

G1: Geçen sene eylül ayında staja ilk başladı̆̆ım gün, Kardiyoloji 1 servisinde ilk defa bir hastadan kan almam söylendi. 40 yaşlarında erkek hasta ve yanında da benim yaşımda olduğunu düşündüğüm kızı vardı. Yanımda hemşire abla ve diğer stajyer arkadaşlarda vardı. Hastanın damarını tesbit ettim, tam alacakken heyecanlandım elim titredi. Hastanın kızı birden çı̆̆llk atmaya başladı. Üstüme yürüdü, engellediler. "Bu ne biçim hemşire, böylelerimi alacak babamın kanını defolun gidin vb" sözler sarfetti. Çok korktum ve heyecanım iyice arttı. $O$ sırada öğretmenim de geldi. Hemşire ablayla birlikte hasta yakınını sakinleştirmeye çalıştılar. Hastada bu durumdan etkilendi ve "sen bırak hemşire alsın" dedi. Ağlayarak odadan çıktım. Olaydan sonra bir süre kan alamadım. Hastaya ve yakınına işlem öncesinde yeterli ve etkili bir açılama yapmadığımın farkında vardım. Güven de verememiştim. Ama bu bana ders oldu, diğer zamanlarda artık hasta odasına işlem için girdiğimde ilk işim hasta yakınını ikna edip odadan çıkarmak oldu.

G2:Gastroenteroloji servisinde staj yaparken, yaklaşık 40 yaşlarında bir kadın hastayla sorun yaşadım. Hastaya mide kanseri teşhisi konmuştu. Hastaneye yeni yatmıştı ve takibe alındı. Saatte bir vital bulguları ölçülecekti (tansiyon, nabız, ateş gibi). Ölçmeye gittiğimde tansiyonunu 100/70 mmHg buldum. Sonucu söyleyince hasta bana bağırmaya başladı. "Ben tansiyon hastasıyım, tansiyonum hiç bu kadar düşük olmuyordu, sen yanlış ölçüyorsun," diğer hastalara döndü (odada 6 hasta vardl), "siz fark etmediniz mi şimdiye kadar" diye onlarl da örgütledi ve hepsi birden bana bağırmaya hakaret etmeye başladılar. Hiç cevap vermedim hemen odadan çıktım ve hemşire ablayı çağırdım. O da ölçtüğünde aynı sonuç çıkınca, hasta emin olsun diye üçüncü bir hemşireyi çă̆ırdık, onunda aynı çıktı ve hasta ikna oldu. Hemşire ablalar, "servisin en çalışkan öğrencisi biz ona güvenmesek zaten ölçtürmeyiz” dediler. Bu sefer özür diledi hastalar benden, ama ben hiçbir işlem için bir daha o odaya gitmedim. Çünkü günlerce hastaların hakaretleri kulaklarımda çınladı durdu. Aynı şeyin tekrarlanacă̆ından korktum açıkçası.

Birde buna benzer bir olayı erkek hasta da yaşadım. O da bana hiç erkek hemşire mi olur, sen hemşire değilsin, teknisyen misin nesin bana dokunma gibi sözler sarfetti. Hiç cevap vermedim ona da. Hemşire ablalar açılama yapınca da "hemşirelik erkeğe yakışmaz bunun eli çok ă̆ırdır çok acıtır, bana dokunmasın" dedi. Bende o hastaya hiçbir bakım uygulamadım.

G3: Bir kadın hasta 50 li yaşlarda kalp hastası, normal rutin kanları almak için yanına gittiğimde "eğer canımı acıtırsan seni döverim elimden kimse alamaz” dedi. Çok etkilendim, üzerimde psikolojik bask hissettim. Cevap vermedim güzelce kanını aldım, açıklamalarımı yaptım. Işslem bittikten sonra da "bir daha hiç kimseyle bu şekilde konuşmayın biz işimizi yapıyoruz" dedim. "Siz öğrencisiniz ondan söyledim, hemşirelere söylemem" deyince pes yani dedim kendi kendime. Çünkü hastane de hastaların ögrencilere her istediklerini yapıp söyleyebilecekleri gibi bir tutum var.

G4: Acil hemodializ ünitesinde staj yaparken bir hastayı 4 saatlik dialize almıştık. Hasta yolda düşüp bayılmış, görenler hastaneye getirmiş, ve buraya sevkedilmişti. Hasta sorunsuz bir şekilde dialize alındı fakat, son 1 saat kala sert bir ifadeyle çıkmak istediğini söyledi. Bölümdeki hemşireler çok kısa zaman kaldığını tedaviyi tamamlarsa kendisi için daha iyi olacağını söylediler, ama o dinlemedi, bağırıp hakaretler yağdırmaya, küfürler etmeye başladı. Öyle ki ă̆za alınmayacak küfürler sarfediyordu. Bunun üzerine hemşireler işlemi sonlandırıp hastayı gönderdiler. Çok şaşırmış ve neden böyle yaptı̆̆ını merak etmiştim. Belki biraz daha sabredip dinlemeye, anlamaya çalışılsaydı sebebi ögrenilirdi diye düşündüm. 
G5: Hastaya intravenöz (I.V) sıvı tedavisi uygulayacaktım. İçerisine kattığım ilacın akış hızını ayarladım. Dakikada sadece 5 damla gitmesi gerekiyordu ve huzl gönderildiği takdirde ani ölüme yol açabilirdi. Hastaya ve yakinina durumun önemini defalarca anlattım. Asla serumun ayartyla oynamamalarinı tembih ettim. Kendimce etkili olmuştum ve onların böyle bir şey yapmayacaklarını düşünüyordum. Aradan 10 dk gibi kısa bir süre geçti ve ben diğer hasta odasından çıkarken yakininın koridorda ki hemşire ablaya serumun bittiğini söylediğini duydum. Korku ve telaş içinde nasıl olur böyle bir şey diye hemşire ablayla odaya girdik ve hastanın serum kıskacını sonuna kadar açıp hızlıca gitmesini sağladığını öğrendik. Yakını da sürekli hastayı suçluyordu. "Telefonla konuşmak için dışarı çıktım, ben yokken açmış odaya girince fark ettim" diyordu. Hasta ise gayet sakin "ne yapayım 2 saat bitmesini mi bekleseydim" diye cevap verdi. Hemen asistan dr lar geldi, hemşireler, biz acil müdahale yaptık yakının yanından uzaklaştırdık yanından hiç ayrılmadan takip ettik. Bunu keşke daha önce yapsaydım diye düşündüm. Neyse ki hastaya bir şey olmadı. Rahatladık ama bu benim için ömür boyu unutmayacağım bir tecrübe oldu. Hastaya ve yakınına bu kadar önemli bir tedavide asla güvenilmeyeceğini öğrendim. Benim çok korktuğumu görünce hemşire abla "korkma güvenini yitirme bak sonuç güzel bitti, ama bundan sonra daha dikkatli ol, çünkü sen ögrencisin, sana birşey olmaz ama bizim başımız yanar" dedi.

G6:Yoğun Bakımda çalışııken, bir erkek hastanın beyin ön lobu alınmıştı. Tedavilerde hep sorun çıkarıyor, bağırıyor çağırıyor, kendisine dokunulmasin istemiyordu. Bende enjeksiyonunu yapamadım, hatta hastadan korktum. Hemşireler geldiler, hastanın ayaklarını bağlayıp sikıca tutup zorla tedaviyi uyguladılar. Doğru bir davranışmıydl, başka neler yapılabilirdi, böyle kolayına kaçmak gerekiyordu gibi sorguladım uzun süre. Ĕger hastaya ameliyat öncesinde tam bir güven duygusu verilseydi ve şefkatle yaklaşılsaydı bu kadar zorlamazdı bizi belki de diye düşündüm. Aradan 6-7 ay geçti,o durumdaki hastalara halen daha asla tedavi uygulayamiyorum.

G10:Venöz yetmezliği olan hastaya 4 lü bandaj uygularken sürekli sorun çıkardl, yaptı̆̆ımız sargıyı eleştirdi, Dolaşım kontrolü yaptığımız halde sargının sık olduğunu söyledi. Hastayı ikna etmek için çok uğraştık. Pek ikna olmasa da gitti. 5 dakika sonra içerde hasta varken girmeye çallştt."Benim sıram daha bitmedi, sargımı düzeltin" diye bağırıp sorun çıkardı. İçeriye aldık, içi rahatlasın diye pansumanı kontrol ettik, onunla daha sevgi dolu bir tonla konuştuk, sargıda pek bir değişiklik olmasa da içi rahatladı ve gitti. Konuşma tonunun ve şeklinin iletişimde çok önemli olduğunu öğrendim. Zor hastalarda bu yöntemi uygulamam gerekir diye düşünüyorum.

Hemşire adaylarının anlattıkları yaşanmışlıklar daha çok klinik uygulamalarla ilgilidir. Bunlar, birçok uygulamayı, iletişim biçimini ve davranış rollerini yaşayarak öğrenmelerini sağlamıştır. Tedavi uygularken daha dikkatli olmaları gerektiğini, hastaya etkili açıklama yapmanın ne kadar önemli olduğunu (G5), zor hastalarla karşılaşıtılarında doğru ve olumlu iletişimle hastaya daha faydalı olacaklarını (G1, G2, G3, G10), ileride meslektaş olacakları hemcinslerinin yanlış davranışlarını rol model almamayı (G6) bu şekilde öğrenmişlerdir. Adölesan döneminin sonunda yetişkinliğe yeni adım atmakta olan hemşire adaylarının kliniklerde yaşadıkları olaylar, onlarda büyük etkiler bırakmıştır. Mesleğe atandıklarında bu deneyimleri onları daha fazla sorumluluk sahibi yapacak ve dikkatli davranmalarını sağlayacaktır.

Klinik uygulama alanları hemşire adaylarına; rol modellerini gözlemleme, sorumluluk alarak uygulama yapabilme, hastanın klinik tablosuna göre davranma, karar verme ve bir ekip üyesi olarak çalışabilme olanağı sağlar. Klinik, öğrenciye okul ortamında öğretilen teorik bilginin pratiğini gerçek ortamda yaşayarak ve yaparak öğrenme firsatı verir. Ayrıca, farklı meslek üyelerinin bir arada uyum içerisinde çalışmasını gözlemlemesine ve bu uyumun bir parçası olmayı benimsemesine yardımcı olur. Hemşire adayları klinik uygulamalara katıldıklarında özgüveni yüksek ve uygulamalarında donanımlı birey olmalarının sağlaması yanında, hasta üzerindeki uygulamalarda hata yapılmasını da en aza indirir (Özcan, 2006:238).

Klinik öğretim hemşire adaylarına psikomotor beceri ve entelektüel öğrenme, problem çözme, zamanı etkin kullanma, profesyonel karar verme becerilerini sağlama, yaratıcı yeteneklerini geliştirme imkânı sunar. Eğitim araştırma hastanelerinde bir kişinin (adayın) psikomotor beceri kazanması için başka birinin (hasta) üzerinde uygulama yapması söz konusudur. Bu bağlamda hem eğitim-öğretim, hem de hastaların tedavi ve bakımının yapıldığı bu ortamlarda etik problemlerin görülme olasılığı yüksektir. Etik problemler, hastaya ve öğrenciye yönelik etik ihlaller, etik çıkmazlar şekline olabilir. Hasta, bakım talep eden taraf, hemşireler ise bakım verme gücünü elinde tutan taraftır. Dolayısıyla bu durum hemşireyi, hastanın kendisine bağımlı olduğu düşüncesine itebilmektedir. Bunun sonucunda hastalar, bağımlı bir şekilde hareket etmelerini gerektiren kurallara uymaya zorlanmaktadır. Bu tür uygulamalardan birisi de, hemşire adaylarının eğitimi amacıyla veya adayların 
hemşirelerin klinik iş yükünü hafifletmesi amacıyla, aday tarafindan sunulacak bakım ve tedavinin hasta tarafindan kabul edilmediği durumlarda, hastaya kabul etmesi zorunluymuş gibi gösterilmesidir. Bu durumda hastanın özerkliği arka planda bırakılmaktadır G2: "Hemşire ablalar, "servisin en çalışkan öğrencisi biz ona güvenmesek zaten ölçtürmeyiz" dediler".

$\mathrm{Bu}$ uygulamanın nedeni hemşirelerin öğrencilerin yararını daha üstün bir değer olarak görmesi olabilir. Belki de hastanın özerkliğinin farkında dahi olmayabilir. Böyle bir eylemde bulunarak hemşireler, iş yüklerini azaltıp kendilerine yarar sağlamak istemiş olabilirler. Hemşire adaylarının yararını gözetirken diğer taraftan hemşirelere oranla daha deneyimsiz oldukları için girişim yaptıkları hastaların zarar görme riski vardır. Örneğin, intramusküler ilaç uygulaması (kas içi) istem edilmiş bir hastaya, hemşire adayı tarafindan uygulama yapılacağı sırada, adayın anksiyeteden dolayı tedirgin ve heyecanlı bir izlenim göstermesi hastane uygulamalarında defalarca karşılaşlan bir durumdur G1:"Hastanın damarın tesbit ettim, tam alacakken heyecanlandım elim titredi. Hastanın kızı birden çı̆̆llk atmaya başladı". Hasta bu durumu fark ettiğinde daha deneyimli olan bir hemşirenin yapmasını istemektedir G1:"Hastada bu durumdan etkilendi ve "sen birak hemşire alsın" dedi. A ğlayarak odadan çıktım. Olaydan sonra bir süre kan alamadım". Hemşire ise hemşire adaylarının yararını düşünerek genellikle uygulamayı öğrencinin yapması için hastayı ikna etme yoluna başvurur ve uygulamayı hemşire adayına yaptırır. Hemşire adayı heyecanlı olduğundan dolayı hata yapma riski de vardır. Hata nedeniyle hastada komplikasyon gelişebilir ya da aday kendisine zarar verebilir. Mesela enjeksiyon yaptıktan sonra eline iğne batırabilir. Hemşire adaylarının bu tür sorunlar yaşamaması için öğretmenleri ve klinik hemşireleri her zaman kendilerinin yanında olmalıdır. Hemşire adayı uygulama yaparken, üzerinde baskı kurmak yerine yapıcı ve destekleyici olmalı ve adayın anksiyetesini azaltacak şekilde etkili bir iletişim kurmalıdırlar (Aydoğan, 2016).

2007 yllında itibaren hemşirelik okullarına tekrar erkek öğrenci alınmaya başlanmıştır. Kadın mesleği olarak bilinen hemşirelikte erkeklerin varlı̆ğ toplumun henüz benimsemediği bir durumdur. Bu nedenle erkek hemşire adaylarının hasta ve hasta yakınları tarafindan ayrımcılığa uğradığı da zaman zaman görülmektedir. G2:"Birde buna benzer bir olayl erkek hasta da yaşadım. $O$ da bana hiç erkek hemşire mi olur, sen hemşire değilsin, teknisyen misin nesin bana dokunma gibi sözler sarfetti”. Bu durumun erkek hemşirelerin uygulama alanlarında artması ile zaman içerisinde benimseneceği düşünülmektedir. Klinik eğitimin beklenilen katkıları sağlayabilmesi, kliniklerde uygulama alanlarının hemşire adaylarının yararına düzenlenmesi ve hasta ve hasta yakını eğitimlerinin de etkili olması sağlanmalıdır (Ergöl ve Kürtüncü, 2013:65). Çünkü hemşirenin hizmetiçi eğitimleri ve hasta ve hasta yakını eğitimleri yetişkin eğitimidir ve yetişkin eğitiminin ilkeleri geçerlidir (Ay, 2007 den akt: Ergöl ve Kürtüncü, 2013).

Yetişkinler kendileri öğrenmeye istekli olmalıdır. Öğrenme aktiviteleri sırasında özgüvenleri zedelenmemelidir. Yetişkinlerin kişisel kaygıları vardır ve güvenli bir ortama gereksinim duyarlar (Gökkoca, 2001 den akt: Ergöl ve Kürtüncü, 2013). Oysa bireylerde özgüven ve öz saygının yitirilmesi, bıkkınlık, yılgınlık, dikkati toplayamama gibi psikolojik sorunlara neden olan iş yerinde ki şiddet hemşire adaylarının uygulama alanı olan sağlık sektörünün önemli bir sorunudur (ILO, 2002 den akt: Ergöl ve Kürtüncü, 2013:69).

\section{Sonuç, Tartışma ve Öneriler}

Hemşirelik mesleği ülkemizde halen kendini tıbbi açıdan kanıtlamaya çalışmaktadır. Oysa tıp modeli, organ veya sistem hastalıkları üzerine yoğunlaşmakta ve hasta bakımının etkili bir iletişim gerektirdiği konusu fazla yer tutmamaktadır. Hemşire hizmet verdiği bireylerle yoğun bir kişilerarası iletişim yaşarken yönelimi genellikle hastanın hastalığı ile ilgili yaşanan tıbbi süreçlere yöneliktir. Kendini tıbbi açıdan geliştiren birçok başarılı hemşire vardır. Bu kişiler hastaya iyi bir fizik bakım verebilmekte, fakat birçok sebepten dolayı hastayı duygu durumuyla birlikte ele almaları her zaman mümkün olmamaktadır. Oysa hasta ve ailesinin yakınmalarının pek çoğu kişiler arasında yaşanan etkileşimler ve iletişim biçimleriyle ilgilidir. Hasta, hasta yakını, hemşireler ve hemşire adayı genç sağlıkçılar arasında yaşanan karşılıklı olumsuzluklar hemşirelik bakımının iletişim becerileri yönünün fiziksel tıbbi bakım yönü kadar gelişmemiş olmasına bağlıdır (Özcan, 2006:16).

Hemşire adaylarının bakım verdikleri kişilerle etkileşimlerinin farkında olmaları, kısa süre sonra mesleğe atandıklarında verecekleri profesyonel hasta bakımının gereklerindendir. Edinecekleri bu özellik aynı zamanda 
mesleki uygulamanın kalitesini de belirleyen bir süreçtir. Bu nedenle adayların, hastayla iletişimlerinin niteliğini bilinçli olarak irdelemeleri ve geliştirmeleri gerekmektedir.

$\mathrm{Bu}$ çalışmada da sağlık hizmeti sunan hemşire adayları ile hasta, hasta yakını ve diğer sağlık personeli arasında yaşanan iletişim sorunları belirlenip, adlandırılarak ortaya konulmuştur. Ayrıca, yapılan görüşmelerde hemşire adaylarının sadece yaşadıkları sorunlar belirlenmekle kalmamış, onların, bu sorunlar karşısında kendi buldukları çözüm önerileri de önemli bulunmuştur.

Hemşire adayları görüşmeler sayesinde yaşadıkları iletişim sorunlarıyla daha bilinçli şekilde yüzleşmişler, farkında olmuşlar ve yaşadıkları deneyimleri bilgiye ve çözüm üretmeye dönüştürerek bundan sonra çaresizlik yaşamayacaklarını belirtmişlerdir. Gelecekte mesleki yaşantılarında hasta bakımı planlarken iletişim becerilerini de mutlaka plana dahil etmeleri beklenmektedir.

Henüz yetişkin birey olma özelliklerini kazanamamış genç adayların, hizmet sundukları hasta bireylerin çoğu yetişkindir ve araştırma da elde edilen bulgular göstermektedir ki henüz benlik gelişimlerini ve kendini tanıma süreçlerini tam olarak geliştiremedikleri gibi yetişkinlerin gelişim dönemleri ve eğitimlerine yönelikte yeterli bilgiye sahip değillerdir. Hastalara sağlık eğitimi yaparken de kendi teorik bilgilerini ancak klinik hemşirelerinin davranışlarını örnek alarak ve kendi kısa deneyimleriyle aktarmaktadırlar.

Hemşire adayları kliniklerde hastalarla, tedaviye uymama veya reddetme, ağlama, bağırma, yakınma, dil problemleri, gereksiz istekler, çevreye zarar verme, odadan kovma, yetersiz hijyen, cinsel obje gibi görülme, önyargılar gibi sorunlar yaşamışlar ve bu sorunlarla da öncelikle empati kurarak veya diğer hemşirelere haber vererek baş etmeye çalışmışlardır. Staj süresi uzadıkça deneyimleri artmış ve hastayı dinleyip anlama, bakım becerisinin artması gibi etkenler kendilerine olan güveni arttırmıştır.

Diğer sağlık personelleriyle de gereksiz ve alakasız iş yükü, acımasız ve anlayışsız davranışlar, şeklinde sorun yaşarken, hasta yakınlarıyla da, hizmetçi gibi görülme, bencillik, agresif davranışlar gibi sorunlar yaşamışlardır.

Staj süresince klinikte tıbbi tedaviye dönük uygulama yaparken, yaşanılan bazı olayları zamanla rutin, sıradan, normal bir davranış gibi görmeye başlayacakken, aslında önemli ve mutlaka çözülmesi gereken iletişim hataları sonucu ortaya çıktı̆ğının farkına varmışlar ve yaşayarak öğrenme sürecini gerçekleştirip, önemli deneyimler kazanmışlardır.

Eğitim süresince aldıkları iletişim derslerinin de daha çok teoriye dayanmasından, gerçek olayları ve yaşanmışlıkları tam olarak yansıtmamasından dolayı ve yetişkin eğitimi kavram ve tekniklerine yer verilmediği için klinik uygulamalarda çok etkili olmadığı anlaşılmıştır.

Her ne kadar araştırmanın kapsamında ekonomiyle ilgili gösterge ve verilere yer verilmemiş ve sağlık iletişimi ile ekonomi ilişkisi yansıtılmamış olsa da; sağlık iletişimi ile sağlık ekonomisi arasında da yüksek düzeyde bir anlamlılık ilişkisi olduğu söylenebilir. Hastanelerde yaşanan iletişim problemleri hastaların kaygı ve korkularını arttırıp tedaviyi reddetmelerini sağladığı için tedavi olma ve iyileşme süresini geciktirdiği açıktır. Böylece hastanede kalma süresi uzayıp, hastaneye başvurma sıklı̆̆ da artacaktır. Bu da kamunun sağlık hizmetleri harcamalarını arttıracaktır. Oysaki olumlu iletişim teknikleri kullanılarak bireylere, hastaneler gibi ikinci basamak sağlık kuruluşlarına gelmeden önce birinci basamak sağlık hizmetlerinde yetişkin eğitim tekniklerinin de uygulandığı etkili, koruyucu ve erken teşhise yönelik kaliteli bir sağlı eğitimi programları sunulursa kamunun sağlı hizmetlerine ayırmış olduğu sağlık payında da önemli bir ölçüde tasarruf sağlanacağı öngörülebilmektedir.

Araştırmanın hemşirelik ve tıp eğitimi veren okullarda daha geniş örneklemde yapılması, Hemşire adaylarına problem odaklı baş etme ve iletişim becerilerini geliştirmeye yönelik eğitimler düzenlenmesi, sağlık personeli yetiştiren tüm eğitim öğretim kurumlarında yetişkin eğitimi adı altında yeni bir ders açılması veya ilgili derslerin kapsamına yetişkin eğitimi konularının dahil edilmesi, mezuniyet sonrası eğitimde, hemşirelere yaşam boyu öğrenme amacına uygun olarak yaşadıkları iletişim sorunlarına ve çözümüne yönelik, etkili iletişim teknikleri eğitimi, verilmeye devam edilmesi, hasta ve hasta yakını eğitimlerine, eğitim seviyelerine uygun olarak etkili dinleme, anlama ve empati yeteneklerini geliştirici konuların eklenmesi önerilmektedir. 


\section{References}

Ergöl, Ş., \& Kürtüncü, M. (2013). Violence experienced by nursing students in clinical practice settings. Journal of Higher Education and Science, 3(1), 65-69.

Koekkoek, B., van Meijel, B., \& Hutschemaekers, G. (2006). " Difficult patients" in mental health care: a review. Psychiatric Services, 57(6), 795-802.

Polat, D.C., \& Akcan, E. (2016). Hemşirelik öğrencilerinin yabancı uyruklu hastalara bakım vermede yaşadığı güçlükler [Difficulties experienced of nursing students who give care foreign patients]. Journal of Anatolia Nursing and Health Sciences, 19, 9-13.

Özcan, A. (2006). Hemşire-hasta ilişkisi ve iletişim [Nurse-patient relationship and communication]. Saray Publications.

Terakye, G. (1994). Hemşirelikte iletişim ve hasta hemşire ilişkileri (2. Basım) [Communication and nursing relations in nursing (2nd Edition)]. Să̆lık Bakanlı̆̆ Sağlık Projesi Yayını, Ankara.

Travelbee, J. (1971). Concept: communication. Ingår i J. Travelbee,(red.). Interpersonal Aspects of Nursing, 2 , 93-116.

Turan, G.B., Mehtap, T.A.N., \& Dayapoğlu, N. (2017). Hemşirelik öğrencilerinin ve klinik hemşirelerin intörn uygulamasına ilişkin görüşlerinin belirlenmesi (determining the opinions of clinic nurses and nursing students about internship). Journal of Anatolia Nursing and Health Sciences, 20(3), 170-179.

Wolf, Z. R., \& Robinson-Smith, G. (2007). Strategies used by clinical nurse specialists in "difficult" clinicianpatient situations. Clinical Nurse Specialist, 21(2), 74-84.

Yıldırım, A., \& Şimşek, H. (2005). Sosyal bilimlerde nitel araştırma yöntemleri[ Qualitative research methods in the social sciences]. Ankara: Seçkin Publications. 